OPEN ACCESS

Edited by:

Michel Cusson,

Natural Resources Canada, Canada

Reviewed by:

Jose Eduardo Serrão,

Universidade Federal de Viçosa, Brazil

Habib Abbasipour,

Shahed University, Iran

*Correspondence:

Ali Golizadeh

golizadeh@uma.ac.ir

Specialty section: This article was submitted to Invertebrate Physiology, a section of the journa

Frontiers in Physiology

Received: 20 January 2019 Accepted: 04 November 2019 Published: 19 November 2019

Citation:

Abedi Z, Golizadeh A, Soufbaf M, Hassanpour M, Jafari-Nodoushan A and Akhavan H-R (2019) Relationship

Between Performance of Carob

Moth, Ectomyelois ceratoniae Zeller

(Lepidoptera: Pyralidae) and Phytochemical Metabolites

in Various Pomegranate Cultivars.

Front. Physiol. 10:1425

doi: 10.3389/fphys.2019.01425

\section{Relationship Between Performance of Carob Moth, Ectomyelois ceratoniae Zeller (Lepidoptera: Pyralidae) and Phytochemical Metabolites in Various Pomegranate Cultivars}

\author{
Zahra Abedi', Ali Golizadeh' ${ }^{*}$, Mahmoud Soufbaf', Mahdi Hassanpour ${ }^{1}$, \\ Ali Jafari-Nodoushan ${ }^{3}$ and Hamid-Reza Akhavan ${ }^{4}$
}

' Department of Plant Protection, Faculty of Agriculture and Natural Resources, University of Mohaghegh Ardabili, Ardabil, Iran, ${ }^{2}$ Department of Plant Protection, Nuclear Agriculture Research School, Nuclear Science and Technology Research Institute, Karaj, Iran, ${ }^{3}$ Agriculture and Natural Resources Research Center of Yazd, Yazd, Iran, ${ }^{4}$ Department of Food Science and Technology, Faculty of Agriculture, Shahid Bahonar University of Kerman, Kerman, Iran

The carob moth, Ectomyelois ceratoniae Zeller (Lepidoptera: Pyralidae), is the main pest of pomegranate, Punica granatum L., in Iran and many parts of the world. In this study, the effects of 11 commercial cultivars of pomegranate (AbanMahi, Esfahani-Daneghermez, Gabri, Gorche-Tafti, Malase-Danesyah, Malase-Yazdi, Shahvare-Daneghermez, Shahvare-Danesefid, Tabolarze-Mehrmahi, Tafti, and TogheGardan) were evaluated on life history variables, nutritional performance, and energy reserves of $E$. ceratoniae under the following laboratory conditions: $30 \pm 1^{\circ} \mathrm{C}, 60 \pm 5 \%$ $\mathrm{RH}$, and a photoperiod of 14:10 ( $\mathrm{L}: \mathrm{D})$ hours. In addition, biochemical characteristics of the tested cultivars were assessed in order to understand any possible correlation between important demographic parameters and nutritional properties with biochemical features of pomegranate juice. Our research showed that various pomegranate cultivars have significant effects on life history, demographical parameters, nutritional indices, and energy reserves of $E$. ceratoniae. The shortest development time was observed on Shahvare-Danesefid cultivar and the longest was on Esfahani-Daneghermez and Malase-Danesyah cultivars. The highest intrinsic rate of increase $\left(r_{m}\right)$ was observed on Shahvare-Danesefid and the lowest was on Esfahani-Daneghermez. Six major anthocyanin compounds were detected in juice of various pomegranate cultivars. Significant positive or negative correlations were observed between life history variables and nutritional characteristics with biochemical traits of pomegranate cultivars. The results indicated that Shahvare-Danesefid was a relatively susceptible pomegranate cultivar and Esfahani-Daneghermez was the least appropriate (most resistant) cultivar for feeding of $E$. ceratoniae, which could be useful in the development of integrated pest management strategies for this pest.

Keywords: Ectomyelois ceratoniae, pomegranate, feeding response, physiological characteristics, demographic parameters, phytochemical metabolites 


\section{INTRODUCTION}

The carob moth, Ectomyelois ceratoniae Zeller (Lepidoptera: Pyralidae), has been recognized as one of the most destructive insect pests of pomegranate and other fruits such as date, almond, carob, nuts, walnut, fig, and pistachio, with a broad distribution in Iran and many tropical and subtropical regions (Warner et al., 1990; Ranjbar et al., 2011; Kishani-Farahani et al., 2012; Soufbaf et al., 2017). Pomegranate, Punica granatum L. (Ponicaceae), is the main host of the carob moth E. ceratoniae in Iran. The larvae feed inside the fruit, resulting in contamination with saprophytic fungi and causing great damage during the cropping season and after harvest, conditions that make the fruit unfit for human consumption (Shakeri, 2004).

The use of resistant cultivars could be an effective approach in integrated pest management (IPM) strategies targeting the carob moth (E. ceratoniae) in pomegranate orchards (Ramzi et al., 2014; Sobhani et al., 2015). Host plant resistance is an alternative for pest management as it is both economically and environmentally acceptable (Golizadeh et al., 2009; Soufbaf et al., 2010; Golizadeh and Abedi, 2016). Evaluating the resistance of various cultivars and crop species to pests may offer useful information about their suitability or unsuitability for the target pest species (Tsai and Wang, 2001). Host plant resistance to insects can also be manipulated using chemical elicitation of secondary metabolites, which can confer resistance to insects (War et al., 2012). Proper use of resistant cultivars in pest management strategies requires knowledge of life table parameters and biological variables of pests (Nawrot et al., 2010; Golizadeh and Abedi, 2017; Gvozdenac et al., 2018; Karimi-Pormehr et al., 2018).

Previously, Norouzi et al. (2008) studied population growth traits of the carob moth fed with different fruits like pomegranate, pistachio, fig, and date; their results showed that the reproductive output of E. ceratoniae on pomegranate and pistachio was higher than that on fig and date. Zare et al. (2013) investigated the biological characteristics of this pest on three pomegranate cultivars and indicated that Malase-danesyah cultivar was the least susceptible host for A. ceratoniae. Mortazavi et al. (2016) evaluated the effects of four diets including pistachio, pomegranate, semi-artificial and artificial diets on this pest, measured some of the biological variables and reported that pomegranate was the most suitable host for E. ceratoniae.

Various defense characteristics of host plants affect the fitness of herbivorous insects (Harvey et al., 2007; NouriGanbalani et al., 2018). Secondary plant chemicals act as feeding inhibitors, deterrents, repellents, and antidigestive compounds that interfere with herbivore physiology and reduce its developmental and survival rates as well as its potential fecundity (War et al., 2011; Nikooei et al., 2015). Pomegranate juice is a potential source of secondary metabolites such as anthocyanins, ellagic acid, phytoestrogenic flavonoids, organic acids, tannins, and antioxidants (Tezcan et al., 2009; Fischer et al., 2011). Anthocyanins are polyphenolic compounds (flavonoids) responsible for the blue, red, and purple colors of most fruits and flowers, which are major compounds of pomegranate juices (Du et al., 1975; Alighourchi et al., 2008; Turfan et al., 2011;
Mirsaeedghazi et al., 2014; Akhavan et al., 2015). Important anthocyanins in pomegranate juice are cyanidin 3-glucoside, cyanidin 3,5-diglucoside, delphinidin 3-glucoside, delphinidin 3,5 diglucoside, pelargonidin 3-glucoside, and pelargonidin 3,5diglucoside (Alighourchi et al., 2008; Turfan et al., 2011; Mirsaeedghazi et al., 2014).

Pomegranate is native to Iran and northern India, however nowadays it is widely cultivated in subtropical regions of the world (Sarkhosh et al., 2009). Iran is the first producer of pomegranate with 6400 ha of pomegranate orchard and total production of 700,000 ton annually. The high quality of pomegranates in Iran has made it an important export commodity and some commercial cultivars have been exported from Iran to other parts of the world (Zare et al., 2013; Ashtari et al., 2019). Therefore, the findings of this study could be used wherever these cultivars are cultivated.

The aim of the present study was to determine whether the life history and nutritional traits of E. ceratoniae vary as a function of the commercial pomegranate cultivar used to rear larvae, using a two-sex life table method. In parallel, we wanted to examine how the biochemical properties and/or nutritional quality of the cultivars we tested can affect life history variables and the nutritional performance of E. ceratoniae. To this end, we quantified some pomegranate compounds, especially major anthocyanins in the juice of various pomegranate varieties, and examined the relationship between their levels and selected biological variables in the pest; prior to this study, no published information was available on the correlation between such variables in E. ceratoniae and plants contents in major anthocyanins and other biochemical compounds of pomegranate juice. Our findings will inform the development of novel carob moth management approaches, including the use of resistant cultivars to reduce pest damage in orchard systems.

\section{MATERIALS AND METHODS}

\section{Pomegranate Cultivars Tested}

Fruits of 11 pomegranate $(P$. granatum) cultivars, including Aban-Mahi, Esfahani-Daneghermez, Gabri, Gorche-Tafti, Malase-Danesyah, Malase-Yazdi, Shahvare-Daneghermez, Shahvare-Danesefid, Tabolarze-Mehrmahi, Tafti, and TogheGardan, which are commercially important in Iran, were selected from mature trees grown in Agricultural and Natural Resources Research Center (ANRRC) of Yazd, Iran ( $31^{\circ} 54^{\prime} 54^{\prime}{ }^{\prime} \mathrm{N}, 54^{\circ}$ $16^{\prime} 37^{\prime}$ ' E). Commercially ripe fresh fruits were randomly selected and harvested from different mature trees to represent the population of the plantation during September 2016. All cultivars were grown within the same geographical zone, using similar agronomic practices. The fruits were transported by a ventilated car to the laboratory, where pomegranates with defects (sunburns, cracks, cuts, and bruises in peel) were discarded. Approximately $10 \mathrm{~kg}(n=60)$ of pomegranate fruit was sampled for each cultivar. Five pomegranates of each cultivar were used for juice extraction, which was kept frozen at $-80^{\circ} \mathrm{C}$ until analysis. The remainder of the fruits was placed in paper bags, stored in refrigerators at $2^{\circ} \mathrm{C}$ and then used for feeding of larvae. 


\section{Insect Rearing}

Larvae used to establish the colony of E. ceratoniae were collected in orchards at the Agricultural and Natural Resources Research Center, Yazd (Iran), between August and October 2016. The pomegranate fruits infested with carob moth larvae were maintained in a growth chamber at $30 \pm 1{ }^{\circ} \mathrm{C}$, relative humidity of $60 \pm 5 \%$, and under a photoperiod of $14 \mathrm{~h}: 10 \mathrm{~h}$ (L:D). New adults that emerged from infested fruits were caught with an electric aspirator and transferred to the mating cages $(50 \mathrm{~cm} \times 50 \mathrm{~cm} \times 100 \mathrm{~cm})$ for $24 \mathrm{~h}$ (Navarro et al., 1986). Adults were fed with a $10 \%$ honey-water solution. After mating and flying in mating cages, 20 pairs of adult moths were placed in a transparent cylindrical plexiglass container $(30 \mathrm{~cm} \times 18 \mathrm{~cm})$ with two holes in the cap covered by organza mesh, and the egg-loaded organza was replaced daily with a new one until nearly all the moths died. The newly laid eggs were separately transferred on 11 pomegranate cultivars. Larvae were reared on each pomegranate cultivar in plastic containers (diameter: $20 \mathrm{~cm}$, depth: $6 \mathrm{~cm}$ ) with a hole covered by a mesh net for ventilation and maintained under the abovementioned standard rearing conditions. Before initiating the experimental work, insects on each pomegranate cultivar were reared for two generations on the same cultivar, and then eggs from the third generation were used to conduct the experiments.

\section{Life History Variables and Body Weight in Immature Stages}

The experiments on each pomegranate cultivar started using same-aged eggs (within $24 \mathrm{~h}$ after oviposition) laid by females reared as larvae on the same cultivar. Sixty eggs of E. ceratoniae were individually transferred into Petri dishes (diameter $9 \mathrm{~cm}$, depth $2 \mathrm{~cm}$ ). In order to ventilation, the middle part of the lid of Petri dish was cut in a circle (diameter $3 \mathrm{~cm}$ ) and then covered with a cloth mesh. The Petri dishes contained a part of pomegranate fruit for feeding of larvae. The fruit pieces were replaced with fresh ones every 2 days during the larval development. The fifth instar larvae of E. ceratoniae reared on each cultivar were weighed separately $24 \mathrm{~h}$ after their emergence. The Petri dishes were checked daily, and the duration of immature stages (egg, larval, pre-pupal, and pupal stages), and immature survival rate were recorded. Pupal weight of $E$. ceratoniae was measured within $24 \mathrm{~h}$ of pupation on each pomegranate cultivar (Sartorius AG Germany GCA803S, $d=0.001 \mathrm{ct}$ ). All experiments on pomegranate cultivars were carried out under the following laboratory conditions: $30 \pm 1^{\circ} \mathrm{C}$, relative humidity of $60 \pm 5 \%$, and a photoperiod of 14:10 (L:D).

\section{Life History Variables in Adults}

After emergence of adult moths, a pair of female and male moths was transferred to the same mating cages as described above and maintained for $24 \mathrm{~h}$. Then, each pair was placed in a transparent plastic tube fitted with mesh lids $(6 \mathrm{~cm}$ diameter and $15 \mathrm{~cm}$ depth). Experimental tubes were checked daily and the number of E. ceratoniae eggs deposited in each tube was recorded. In this way, each pair was daily transferred to a new tube, the number of eggs laid by adults was counted, and the experiments were continued up to the death of the last adult female and male moth. To supply a source of carbohydrate for adult feeding, a small cotton wick soaked in $10 \%$ honey solution was inserted into the egg- laying container. In this experiment, adult preoviposition period (APOP: the time between the emergence of an adult female and the start of its oviposition), total preoviposition period (TPOP: the duration from egg to first oviposition), oviposition period, fecundity (eggs laid during the reproductive period), and adult longevity were recorded. Resulting data were analyzed based on the age-stage, two-sex life table model developed by Chi and Liu (1985) and Chi (1988).

\section{Nutritional Indices and Quantitative Analysis of Stored Macromolecules in Larvae}

The gravimetric method described by Waldbauer (1968) was used to determine the nutritional responses (larval weight, food consumed, feces produced, and weight gain) of E. ceratoniae fourth-instar larvae on 11 pomegranate cultivars (40 replicates for each cultivar). Nutritional indices were evaluated on the basis of dry weight. Fourth-instar larvae were placed on fruit of each pomegranate cultivar after weighing and transfer into Petri dishes $(9 \mathrm{~cm}$ in diameter, depth $2 \mathrm{~cm})$. Larval weight was recorded daily, before and after feeding, for a 1-week experimental period. The fresh food provided, the remaining food, and feces at the end of each experiment were weighed daily. The quantity of ingested food was calculated by subtracting the weight of remaining food at the end of each experiment from the weight of fresh food at the beginning. To obtain the dry weight percentage of the food and larvae, 20 specimens of food and larvae for each cultivar were weighed, oven-dried at $60^{\circ} \mathrm{C}$ for $48 \mathrm{~h}$, and then weighed again. Nutritional indices of larval E. ceratoniae were calculated using the Waldbauer (1968) as follows: efficiency of conversion of ingested food $(\mathrm{ECI})=\mathrm{P} / \mathrm{E}$; efficiency of conversion of digested food $(\mathrm{ECD})=\mathrm{P} / \mathrm{E}-\mathrm{F}$; relative consumption rate $(\mathrm{RCR})=\mathrm{E} / \mathrm{A}^{*} \mathrm{~T}$; relative growth rate $(\mathrm{RGR})=\mathrm{P} / \mathrm{A}^{*} \mathrm{~T}$; where $\mathrm{A}=$ mean dry weight of larvae over the feeding period $(\mathrm{g}), \mathrm{E}=$ dry weight of food consumed (g), F = dry weight of feces produced (g), $\mathrm{P}=$ dry weight gain of larvae $(\mathrm{g})$, and $\mathrm{T}=$ duration of feeding period (day).

To measure the energy content of E. ceratoniae larvae (protein and glycogen contents), we used the whole body of fourth-instar larvae feeding on each pomegranate cultivar. All assays were replicated three times.

Total protein concentration of individual larvae was assessed using the Bradford (1976), bovine serum albumin (BSA) as a standard.

Glycogen content was assayed using the anthrone reagent as described (Yuval et al., 1998) and whole body lipid of E. ceratoniae larva was extracted according to the Van Handel (1985) method.

\section{Biochemical Traits of Pomegranate Cultivars}

Biochemical traits of pomegranate were assessed to examine the correlation between the main life-table parameters, nutritional 
indices, and energy reserves of E. ceratoniae, on the one hand, and biochemical compounds founds in various pomegranate cultivars. All assays (each pomegranate cultivar) were done in three replicates. All biochemical metabolites of pomegranate were measured using pomegranate juice. Before juice extraction, fruits of 11 pomegranate cultivars (five from each cultivar) were washed in cold tap water and dried, and the damaged pomegranates were discarded. The juicy sacs from fruit pericarp were separated by hand and the juices were obtained using a manual juicer via pressing the arils. The juice samples $(200 \mathrm{~mL})$ were immediately centrifuged $\left(10,000 \mathrm{rpm}\right.$ for $2 \mathrm{~min}$ at $\left.4^{\circ} \mathrm{C}\right)$, divided into small vials and frozen at $-80^{\circ} \mathrm{C}$ until analysis (Alighourchi et al., 2013).

\section{Anthocyanin Analysis}

Delphinidin 3,5-diglucoside, delphinidin 3-diglucoside, cyanidin 3,5-diglucoside, cyanidin 3-glucoside, pelargonidin 3,5-diglucoside, and pelargonidin 3-glucoside standards were purchased from Apin Chemicals, Co., Ltd. (Oxon, United Kingdom). Anthocyanins in juices were determined by high-performance liquid chromatography (HPLC) using an HPLC system equipped with an Empower software, a pump (Waters 600), a Rheodyne $7125 \mathrm{i}$ six-way injector with $20 \mu \mathrm{L}$ sample loop, and a UV-Vis detector (Waters model 2487). Twenty microliters of purified juice was injected onto the HPLC column. Calculation of concentrations was based on the external standard method and anthocyanins were identified by comparison of their retention times with those of pure standards.

\section{Total Protein Concentration Measurements}

Protein content of pomegranate cultivars we tested was determined according to the Bradford (1976) using BSA as a standard.

\section{Carbohydrate Content Determination}

The carbohydrate content was assayed using the Anthrone reagent (0.05\% in sulfuric acid) (Bemani et al., 2012).

\section{Condensed Tannin (CT) Content Determination}

Condensed tannin content reactive to Sulphosphovanillin reagent (orthophosphoric acid $0.6 \%$ aqueous vanillin solution 4:1 v/v) was analyzed according to Tanner and Brunner (1979). Quantification of condensed tannin content was carried out using calibration curves of catechin as an external standard.

\section{Total Monomeric Anthocyanin Pigment Content (TMAC)}

Total anthocyanin contents were measured by $\mathrm{pH}$ differential method using two buffer systems: potassium chloride, $\mathrm{pH} 1.0$ $(0.025 \mathrm{M})$ and sodium acetate, $\mathrm{pH} 4.5(0.4 \mathrm{M})$ (Wrolstad et al., 2005). Results were expressed as mg of cyaniding-3-glucoside per $100 \mathrm{~mL}$ of pomegranate juice.

\section{Total Phenolic Content (TPC)}

Total phenolic content was determined using Folin-Ciocalteu method described by Tezcan et al. (2009). The result was expressed as milligram of gallic acid equivalent per $100 \mathrm{~mL}$ of pomegranate juice.

\section{Flavonoid Content Determination}

Total flavonoid content was measured by aluminum chloride colorimetric assay (Jia et al., 1999). Total flavonoid content was expressed as milligram catechin equivalents per one milliliter of extract.

\section{Antioxidant Activity Determination}

Evaluation of antioxidant activity was done based on radical scavenging properties of the juice using 2,2-diphenyl-1picrylhydrazyl (DPPH) method (Tezcan et al., 2009).

\section{Titrable Acidity (TA), pH, and Soluble Solids Content}

Total titrable acidity was determined by titration to $\mathrm{pH}=8.1$ with $0.1 \mathrm{M} \mathrm{NaOH}$ solution and expressed as grams citric acid per liter of juice. The $\mathrm{pH}$ measurements were performed using a digital $\mathrm{pH}$ meter at $20^{\circ} \mathrm{C}$. Total soluble solid content (SSC) was determined with a digital refractometer. Results were reported as ${ }^{\circ}$ Brix at $20^{\circ} \mathrm{C}$ (Alighourchi et al., 2008).

\section{Statistical Analysis}

Before analysis, all data were examined for normality using Kolmogorov-Smirnov test by SPSS v. 16.0 statistical program (SPSS Inc, 2007). The life table parameters including the intrinsic rate of increase $\left(r_{m}\right)$, gross reproductive rate $(G R R)$, net reproductive rate $\left(R_{0}\right)$, mean generation time $(T)$, and finite rate of increase $(\lambda)$ were analyzed according to the age-stage, two-sex life table using TWOSEX-MSChart (Chi, 2016). The variability of life table parameters was estimated in bootstrap procedure and the bootstrap values on 11 pomegranate cultivars were compared using paired bootstrap test $(P<0.05)($ Chi, 2016). The developmental time, immature survival rate, and fecundity were used for calculation of age-specific survivorship $\left(l_{x}\right)$ and age-specific fecundity $\left(m_{x}\right)$ for both male and female (Chi and Su, 2006). Additionally, weights of fifth instar larvae and pupae, nutritional indices, energy reserves of E. ceratoniae and biochemical traits of various pomegranate cultivars were analyzed by one-way ANOVA with mean separation at 5\% level of significance by Tukey test (SAS Institute, 2002). Correlation between some important demographic parameters, nutritional indices, and storage macromolecule amounts of E. ceratoniae with biochemical compounds of various pomegranate cultivars was evaluated through Pearson's correlation test. A dendrogram of pomegranate cultivars based on life table parameters, nutritional indices, and storage macromolecules of E. ceratoniae on tested pomegranate cultivars was constructed by Ward's method using SPSS. 


\section{RESULTS}

\section{Immature Life History Variables and Body Weight}

Developmental time of E. ceratoniae on various pomegranate cultivars is given in Table 1. There were significant differences in mean incubation periods among the pomegranate cultivars. The longest egg incubation period was on the Esfahani-Daneghermez and Malase-Danesyah cultivars, while the shortest was observed on the Toghe-Gardan cultivar. The longest larval period was seen on the Esfahani-Daneghermez cultivar and the shortest on the Shahvare-Danesefid cultivar. The pre-pupal period of E. ceratoniae on the Shahvare-Danesefid cultivar was significantly shorter than on the other cultivars except for Malase-Yazdi. The longest pupal period was observed on the EsfahaniDaneghermez and Malase-Danesyah cultivars, whereas a shorter period was observed on the Toghe-Gardan cultivar. The shortest developmental time from egg to adult emergence was on the Shahvare-Danesefid cultivar (36.41 \pm 0.31 days) and the longest was on the Esfahani-Daneghermez (41.80 \pm 0.26 days) and Malase-Danesyah (41.46 \pm 0.28 days) cultivars. The immature survival rate ranged from $0.68 \pm 0.06$ to $0.87 \pm 0.05$ with the lowest and highest survival rates observed on EsfahaniDaneghermez and Shahvare-Danesefid cultivars, respectively (Table 1). Finally, E. ceratoniae displayed the highest sex ratio on the Shahvare-Danesefid cultivar, while the lowest one was seen on the Esfahani-Daneghermez and Malase Danesyah cultivars (Table $\mathbf{1}$ ).

The age-specific survival rate $\left(l_{x}\right)$ of E. ceratoniae on different cultivars is shown in Figure 1. Overall, age-specific survival rate curves were similar among insects fed different cultivars. However, female adults were longer-lived on the Aban-Mahi cultivar and the $l_{x}$ curve was more extended on this cultivar.

Table 2 shows the weight of fifth instars and pupae of E. ceratoniae when reared on various pomegranate cultivars. The mean weight of fifth-instar larvae varied from $0.0425 \pm 0.001 \mathrm{~g}$ on the Malase-Danesyah cultivar to $0.0615 \pm 0.001 \mathrm{~g}$ on Shahvare-Danesefid $(F=31.66 ; \mathrm{df}=10,546 ; P<0.0001)$. Moreover, pupal weight showed significant variation as a function of the pomegranate cultivar tested $(F=25.35$; df $=10,514$; $P<0.0001)$. The highest values were observed on the ShahvareDanesefid and Toghe-Gardan cultivars and the lowest ones were recorded on the Malase-Danesyah and Esfahani-Daneghermez cultivars (Table 2).

\section{Longevity and Reproductive Variables}

The data on pre-oviposition and oviposition periods, fecundity and lifespan of E. ceratoniae adults on the tested pomegranate cultivars are presented in Table 3. Significant effects were observed for adult pre-oviposition period (APOP) of E. ceratoniae. Total pre-oviposition period (TPOP) varied significantly as a function of the pomegranate cultivars used as food source. The TPOP was longest on the EsfahaniDaneghermez cultivar and shortest on Toghe-Gardan. Moreover, the oviposition period was the longest when E. ceratoniae females were reared on the Shahvare-Danesefid cultivar and the shortest

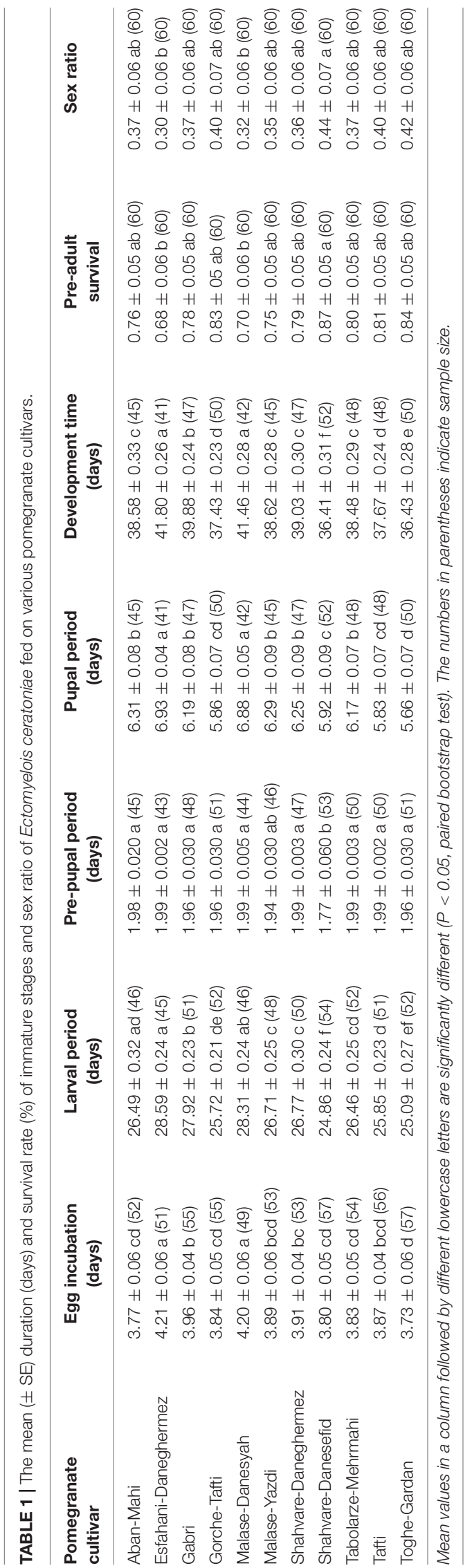




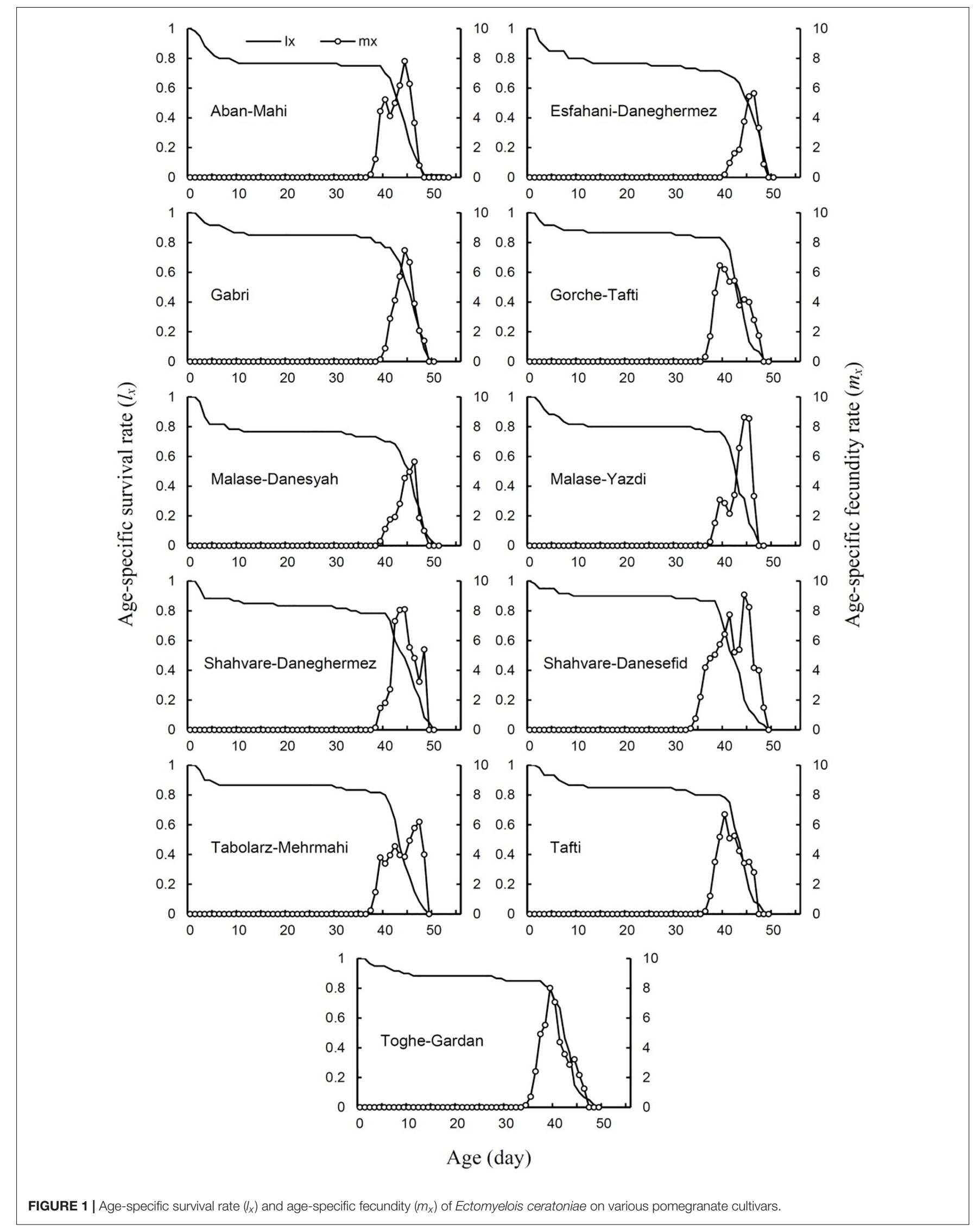


TABLE 2 | The mean ( \pm SE) (g) weight of fifth instar larvae and pupa stage of Ectomyelois ceratoniae reared on various pomegranate cultivars.

\begin{tabular}{lll}
\hline Pomegranate cultivar & \multicolumn{1}{c}{ Fifth instar larvae } & \multicolumn{1}{c}{ Pupa } \\
\hline Aban-Mahi & $0.0504 \pm 0.001 \mathrm{~cd}(46)$ & $0.0410 \pm 0.001 \mathrm{bc}(45)$ \\
Esfahani-Danehghermez & $0.0435 \pm 0.001 \mathrm{ef}(45)$ & $0.0347 \pm 0.001 \mathrm{e} \mathrm{(41)}$ \\
Gabri & $0.0468 \pm 0.001 \mathrm{def}(51)$ & $0.0387 \pm 0.001 \mathrm{~cd}(47)$ \\
Gorche-Tafti & $0.0542 \pm 0.001 \mathrm{bc}(52)$ & $0.0418 \pm 0.001 \mathrm{abc}(50)$ \\
Malase-Danehsyah & $0.0425 \pm 0.001 \mathrm{f}(46)$ & $0.0342 \pm 0.001 \mathrm{e}(42)$ \\
Malase-Yazdi & $0.0466 \pm 0.001 \mathrm{def}(48)$ & $0.0362 \pm 0.001 \mathrm{de}(45)$ \\
Shahvare-Danehghermez & $0.0455 \pm 0.001 \mathrm{def}(50)$ & $0.0391 \pm 0.001 \mathrm{bcd}(47)$ \\
Shahvare-Danehsefid & $0.0615 \pm 0.001 \mathrm{a} \mathrm{(54)}$ & $0.0442 \pm 0.001 \mathrm{a} \mathrm{(52)}$ \\
Tabolarze-Mehrmahi & $0.0484 \pm 0.001 \mathrm{de} \mathrm{(52)}$ & $0.0393 \pm 0.001 \mathrm{bcd}(48)$ \\
Tafti & $0.0566 \pm 0.001 \mathrm{~b}(51)$ & $0.0420 \pm 0.001 \mathrm{ab}(48)$ \\
Toghe-Gardan & $0.0581 \pm 0.002 \mathrm{ab}(52)$ & $0.0448 \pm 0.001 \mathrm{a} \mathrm{(50)}$
\end{tabular}

Mean values in a column followed by different lowercase letters are significantly different on the basis of ANOVA with Tukey test $(P<0.05)$. The numbers in parentheses indicate sample size.

when reared on the Esfahani-Daneghermez, Malase-Danesyah, and Malase-Yazdi cultivars. Total fecundity (mean number of eggs laid during the reproductive period) of E. ceratoniae varied significantly as a function of the 11 pomegranate cultivars tested; the highest values were observed on the ShahvareDanesefid $(82.74 \pm 2.01$ eggs $)$ and Toghe-Gardan $(70.46 \pm 2.30$ eggs) cultivars and the lowest was on Esfahani-Daneghermez (36.91 \pm 1.35 eggs) (Table 3 ).

Age-specific fecundity rates $\left(m_{x}\right)$ for E. ceratoniae reared on the pomegranate cultivars tested are shown in Figure 1. The width of the $m_{x}$ curve (i.e., the fecundity period) was the greater on the Shahvare-Danesefid cultivar than the others.

Longevity of both male and female adults of E. ceratoniae was lowest when larvae were reared on the Esfahani-Daneghermez, Malase-Danesyah, and Malase-Yazdi cultivars (Table 3).

\section{Adult Life Table Parameters}

Life tables were constructed from developmental time, survival, and fecundity data (Table 4). All computed parameters were significantly affected by the pomegranate cultivar. Insects reared on Shahvare-Danesefid had the highest gross reproductive rate $(G R R)$ while those reared on Esfahani-Daneghermez showed the lowest $G R R$ value. The net reproductive rate $\left(R_{0}\right)$ was the lowest on the Esfahani-Daneghermez cultivar and the highest on the Shahvare-Danesefid cultivar. The intrinsic rate of increase $\left(r_{m}\right)$ values ranged from $0.053 \pm 0.004$ to $0.090 \pm 0.004$ female progeny per female per day on the pomegranate cultivars under study (Table 4). The $r_{m}$ value was highest when E. ceratoniae were reared on the Shahvare-Danesefid cultivar and lowest on the Esfahani-Daneghermez cultivar. Variation in the finite rate of increase $(\lambda)$ was similar to that observed for the intrinsic rate of increase while the mean generation time $(T)$ of E. ceratoniae was shortest on the Toghe-Gardan cultivar (Table 4).

\section{Nutritional Indices and Storage Macromolecules of Larvae}

Measurements of the nutritional performance of E. ceratoniae fourth-instar larvae are shown in Table 5. Nutritional indices were significantly different among larvae feeding on various pomegranate cultivars. The larvae fed on Shahvare-Danesefid showed a higher level of food consumption as compared with those reared on other cultivars $(F=23.15$; $\mathrm{df}=10$, 439; $P<0.0001)$. Also, the highest weight gain of larvae $(F=47.91 ; \mathrm{df}=10,439 ; P<0.0001)$ was observed when larvae were fed on Shahvare-Danesefid (Table 5). Larvae reared on the Shahvare-Danesefid and Gorche-Tafti cultivars showed the highest efficiency of conversion of ingested food (ECI) $(F=22.89 ; \mathrm{df}=10,439 ; P<0.0001)$ as well as efficiency of conversion of digested food (ECD) $(F=22.77$; $\mathrm{df}=10,439$; $P<0.0001)$ compared with larvae fed on the other cultivars (Table 5). The highest RCR $(F=2.48$; $\mathrm{df}=10,439 ; P=0.0068)$ was observed on the Esfahani-Daneghermez and TabolarzeMehrMahi cultivars, while larvae reared on Gorche-Tafti had a lowest RCR. In addition, the highest value of relative growth rate (RGR) $(F=7.93 ; \mathrm{df}=10,439 ; P<0.0001)$ was obtained for larvae reared on the Shahvare-Danesefid cultivar (Table 5).

TABLE 3 | Biological parameters of Ectomyelois ceratoniae adults reared on various pomegranate cultivars.

\begin{tabular}{|c|c|c|c|c|c|c|}
\hline $\begin{array}{l}\text { Pomegranate } \\
\text { cultivar }\end{array}$ & $\begin{array}{l}\text { APOP } \\
\text { (days) }\end{array}$ & $\begin{array}{l}\text { TPOP } \\
\text { (days) }\end{array}$ & $\begin{array}{l}\text { Oviposition period } \\
\text { (days) }\end{array}$ & $\begin{array}{c}\text { Fecundity } \\
\text { (no. eggs laid) }\end{array}$ & $\begin{array}{c}\text { Female adult } \\
\text { longevity (days) }\end{array}$ & $\begin{array}{c}\text { Male adult } \\
\text { longevity (days) }\end{array}$ \\
\hline Aban-Mahi & $1.04 \pm 0.05$ b (22) & $39.92 \pm 0.41$ ef $(22)$ & $4.55 \pm 0.23 \mathrm{~cd}(22)$ & $58.61 \pm 2.05$ c (22) & $6.27 \pm 0.25 \mathrm{bc}(22)$ & 0.41 工 \\
\hline Esfahani-Daneghermez & $1.22 \pm 0.10 a b(18)$ & $43.11 \pm 0.40$ a (18) & $3.39 \pm 0.18$ e (18) & $36.91 \pm 1.35 f(18)$ & $5.33 \pm 0.19 d(18)$ & $4.47 \pm 0.23 d(23)$ \\
\hline Gabri & $1.18 \pm 0.08 \mathrm{ab}(22)$ & $41.64 \pm 0.28$ bc (22) & $4.22 \pm 0.18 d(22)$ & $51.51 \pm 1.94 \mathrm{~d}(22)$ & $6.14 \pm 0.23 c(22)$ & $5.76 \pm 0.23 \mathrm{abc}(25)$ \\
\hline Gorche-Tafti & $1.17 \pm 0.07 \mathrm{ab}(24)$ & $38.52 \pm 0.32$ gh (24) & $5.03 \pm 0.25 \mathrm{abc}(24)$ & $67.03 \pm 2.28$ b (24) & $6.82 \pm 0.27$ abc (24) & $5.96 \pm 0.14 \mathrm{ab}(26)$ \\
\hline Malase-Danesyah & $1.16 \pm 0.09 \mathrm{ab}(19)$ & $42.23 \pm 0.45 a b(19)$ & $3.68 \pm 0.19$ e (19) & $40.37 \pm 1.63$ ef $(19)$ & $5.53 \pm 0.16 d(19)$ & $4.57 \pm 0.22 d(23)$ \\
\hline Malase-Yazdi & $1.28 \pm 0.10 \mathrm{a}(21)$ & $40.30 \pm 0.49$ de $(21)$ & $3.67 \pm 0.20$ e $(21)$ & $44.97 \pm 2.02$ e $(21)$ & $5.48 \pm 0.23 d(21)$ & $4.91 \pm 0.21 \mathrm{~d}(24)$ \\
\hline Shahvare-Daneghermez & $1.18 \pm 0.08 \mathrm{ab}(22)$ & $41.09 \pm 0.33 \mathrm{~cd}(22)$ & $5.01 \pm 0.17 \mathrm{abc}(22)$ & $60.02 \pm 1.99$ c (22) & $6.90 \pm 0.23 a b(22)$ & $5.72 \pm 0.15 \mathrm{abc}(25)$ \\
\hline Shahvare-Danesefid & $1.11 \pm 0.06 \mathrm{ab}(26)$ & $37.45 \pm 0.52$ hi (26) & $5.50 \pm 0.20 \mathrm{a}(26)$ & $82.74 \pm 2.01 \mathrm{a}(26)$ & $7.04 \pm 0.21 \mathrm{a}(26)$ & $5.84 \pm 0.18 a b c(26)$ \\
\hline Tabolarze-Mehrmahi & $1.09 \pm 0.06 \mathrm{ab}(22)$ & $39.72 \pm 0.43$ ef $(22)$ & $4.64 \pm 0.23 \mathrm{bcd}(22)$ & $51.33 \pm 2.08 \mathrm{~d}(22)$ & $6.28 \pm 0.23$ bc (22) & $5.51 \pm 0.20$ bc (26) \\
\hline Tafti & $1.21 \pm 0.09 a b(24)$ & $38.92 \pm 0.37 \mathrm{fg}(24)$ & $4.66 \pm 0.23$ bcd $(24)$ & $60.34 \pm 2.29 c(24)$ & $6.82 \pm 0.27 \mathrm{abc}(24)$ & $5.96 \pm 0.15 a b(24)$ \\
\hline Toghe-Gardan & $1.08 \pm 0.05 \mathrm{ab}(25)$ & $37.23 \pm 0.35$ i (25) & $5.16 \pm 0.20 \mathrm{ab}(25)$ & $70.46 \pm 2.30 \mathrm{a}(25)$ & $7.19 \pm 0.27 \mathrm{a}(25)$ & $6.04 \pm 0.16 \mathrm{a}(25)$ \\
\hline
\end{tabular}

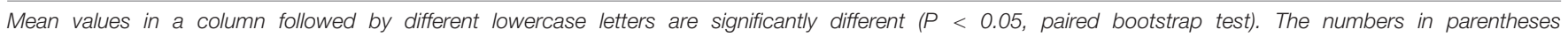
indicate sample size. APOP, adult pre-oviposition period; TPOP, total pre-oviposition period. 
Values measured for the energy reserves of E. ceratoniae fourth-instar larvae on various pomegranate cultivars are given in Table 6. There was significant variation in energy contents of E. ceratoniae larvae reared on different cultivars. The highest whole-body protein content of larvae $(F=16.05 ; \mathrm{df}=10,32$; $P=0.0068)$ was observed in those fed on the Shahvare-Danesefid cultivar $(F=3.16 ; \mathrm{df}=10,32 ; P=0.0118)$. Similarly, the larvae fed on this cultivar showed the highest whole-body glycogen

TABLE 4 | Mean ( \pm SE) of two-sex life-table parameters for Ectomyelois ceratoniae reared on various pomegranate cultivars.

\begin{tabular}{|c|c|c|c|c|c|c|}
\hline Pomegranate cultivar & $\begin{array}{l}\text { Sample } \\
\text { size (n) }\end{array}$ & $\begin{array}{c}\text { GRR } \\
\text { (female/female) }\end{array}$ & $\begin{array}{c}R_{0} \\
\text { (female/female) }\end{array}$ & $\begin{array}{c}r_{m} \\
\text { (female/female/day) }\end{array}$ & $\begin{array}{c}\lambda \\
\text { (female/day) }\end{array}$ & $T$ (days) \\
\hline Aban-Mahi & 60 & $44.98 \pm 6.71 \mathrm{~b}$ & $21.59 \pm 3.65 b c$ & $0.072 \pm 0.004 \mathrm{cde}$ & $1.075 \pm 0.004 \mathrm{cde}$ & $42.50 \pm 0.48 c$ \\
\hline Gabri & 60 & $35.44 \pm 5.51 \mathrm{bc}$ & $19.05 \pm 3.30 \mathrm{bcd}$ & $0.066 \pm 0.004$ def & $1.068 \pm 0.004 \mathrm{def}$ & $44.26 \pm 0.30 \mathrm{~b}$ \\
\hline Gorche-Tafti & 60 & $46.48 \pm \pm 7.40 \mathrm{~b}$ & $26.83 \pm 4.49 a b$ & $0.080 \pm 0.004 \mathrm{abc}$ & $1.083 \pm 0.005 a b c$ & $41.10 \pm 0.33 \mathrm{fg}$ \\
\hline Malase-Danesyah & 60 & $25.85 \pm 4.64 c$ & $12.71 \pm 2.47 d$ & $0.057 \pm 0.005 \mathrm{fg}$ & $1.058 \pm 0.005 \mathrm{fg}$ & $44.56 \pm 0.40 \mathrm{ab}$ \\
\hline Shahvare-Danesefid & 60 & $74.64 \pm 10.55 a$ & $36.05 \pm 5.60 \mathrm{a}$ & $0.090 \pm 0.004 a$ & $1.093 \pm 0.004 \mathrm{a}$ & $40.02 \pm 0.50 \mathrm{gh}$ \\
\hline Tabolarze-Mehrmahi & 60 & $45.40 \pm 8.44 b$ & $18.88 \pm 3.31 \mathrm{bcd}$ & $0.069 \pm 0.004$ cde & $1.071 \pm 0.005$ cde & $42.34 \pm 0.44 \mathrm{cde}$ \\
\hline Tafti & 60 & $41.03 \pm 5.85 b$ & $24.01 \pm 3.84 \mathrm{abc}$ & $0.077 \pm \pm 0.004 \mathrm{bcd}$ & $1.080 \pm 0.004 \mathrm{bcd}$ & $41.34 \pm 0.34$ ef \\
\hline Toghe-Gardan & 60 & $46.29 \pm 7.84 b$ & $29.29 \pm 4.58 \mathrm{ab}$ & $0.084 \pm 0.004 \mathrm{ab}$ & $1.088 \pm 0.004 \mathrm{ab}$ & $39.90 \pm 0.32 h$ \\
\hline
\end{tabular}

Mean values in a column followed by different lowercase letters are significantly different $\left(P<0.05\right.$, paired bootstrap test). GRR, gross reproductive rate; $R_{0}$, net reproductive rate; $r_{m}$, intrinsic rate of increase; $\lambda$, finite rate of increase; $T$, mean generation time.

TABLE 5 | The mean ( \pm SE) nutritional indices of Ectomyelois ceratoniae reared on various pomegranate cultivars.

\begin{tabular}{lcllllll}
\hline Pomegranate cultivar & $\begin{array}{c}\text { Sample } \\
\text { size (n) }\end{array}$ & $\begin{array}{c}\text { Food consumed } \\
\text { (g/larvae) }\end{array}$ & $\begin{array}{c}\text { Larval weight } \\
\text { gain (g) }\end{array}$ & ECl (\%) & ECD (\%) & RCR (g/g/day) & RGR (g/g/day) \\
\hline Aban-Mahi & 40 & $2.70 \pm 0.06 \mathrm{~cd}$ & $0.020 \pm 0.002 \mathrm{de}$ & $1.93 \pm \pm 0.12 \mathrm{bc}$ & $1.99 \pm \pm 0.13 \mathrm{bc}$ & $4.11 \pm \pm 0.14 \mathrm{ab}$ & $0.076 \pm \pm 0.004 \mathrm{bc}$ \\
Esfahani-Danehghermez & 40 & $2.59 \pm \pm 0.04 \mathrm{~d}$ & $0.014 \pm 0.001 \mathrm{e}$ & $1.44 \pm \pm 0.08 \mathrm{~d}$ & $1.49 \pm \pm 0.08 \mathrm{~d}$ & $4.53 \pm \pm 0.14 \mathrm{a}$ & $0.064 \pm \pm 0.004 \mathrm{c}$ \\
Gabri & 40 & $2.65 \pm \pm 0.05 \mathrm{~cd}$ & $0.016 \pm 0.001 \mathrm{e}$ & $1.57 \pm \pm 0.09 \mathrm{~cd}$ & $1.62 \pm \pm 0.09 \mathrm{~cd}$ & $4.24 \pm \pm 0.14 \mathrm{ab}$ & $0.065 \pm \pm 0.004 \mathrm{c}$ \\
Gorche-Tafti & 40 & $3.10 \pm 0.07 \mathrm{~b}$ & $0.031 \pm \pm 0.008 \mathrm{~b}$ & $2.69 \pm \pm 0.10 \mathrm{a}$ & $2.78 \pm \pm 0.10 \mathrm{a}$ & $3.41 \pm \pm 0.16 \mathrm{~b}$ & $0.090 \pm \pm 0.005 \mathrm{ab}$ \\
Malase-Danehsyah & 40 & $2.63 \pm \pm 0.05 \mathrm{~cd}$ & $0.015 \pm \pm 0.009 \mathrm{e}$ & $1.47 \pm \pm 0.08 \mathrm{~d}$ & $1.52 \pm \pm 0.08 \mathrm{~d}$ & $4.36 \pm \pm 0.14 \mathrm{ab}$ & $0.063 \pm \pm 0.004 \mathrm{c}$ \\
Malase-Yazdi & 40 & $2.62 \pm 0.05 \mathrm{~cd}$ & $0.016 \pm 0.004 \mathrm{e}$ & $1.59 \pm \pm 0.10 \mathrm{~cd}$ & $1.64 \pm \pm 0.10 \mathrm{~cd}$ & $4.25 \pm \pm 0.14 \mathrm{ab}$ & $0.065 \pm \pm 0.004 \mathrm{c}$ \\
Shahvare-Danehghermez & 40 & $2.66 \pm \pm 0.04 \mathrm{~cd}$ & $0.017 \pm 0.003 \mathrm{e}$ & $1.69 \pm \pm 0.11 \mathrm{bcd}$ & $1.74 \pm \pm 0.11 \mathrm{bcd}$ & $4.20 \pm \pm 0.16 \mathrm{ab}$ & $0.067 \pm \pm 0.004 \mathrm{c}$ \\
Shahvare-Danehsefid & 40 & $3.62 \pm 0.07 \mathrm{a}$ & $0.039 \pm \pm 0.006 \mathrm{a}$ & $2.84 \pm \pm 0.08 \mathrm{a}$ & $2.92 \pm \pm 0.08 \mathrm{a}$ & $3.74 \pm \pm 0.12 \mathrm{ab}$ & $0.105 \pm \pm 0.003 \mathrm{a}$ \\
Tabolarze-Mehrmahi & 40 & $2.76 \pm 0.07 \mathrm{~cd}$ & $0.019 \pm 0.001 \mathrm{de}$ & $1.78 \pm \pm 0.12 \mathrm{bcd}$ & $1.84 \pm \pm 0.13 \mathrm{bcd}$ & $4.63 \pm \pm 0.64 \mathrm{a}$ & $0.074 \pm \pm 0.007 \mathrm{bc}$ \\
Tafti & 40 & $2.80 \pm \pm 0.09 \mathrm{~cd}$ & $0.023 \pm 0.001 \mathrm{~cd}$ & $2.09 \pm \pm 0.10 \mathrm{~b}$ & $2.18 \pm \pm 0.11 \mathrm{~b}$ & $3.91 \pm \pm 0.17 \mathrm{ab}$ & $0.080 \pm \pm 0.005 \mathrm{bc}$ \\
Toghe-Gardan & 40 & $2.89 \pm 0.08 \mathrm{bc}$ & $0.025 \pm \pm 0.003 \mathrm{c}$ & $2.14 \pm \pm 0.09 \mathrm{~b}$ & $2.20 \pm \pm 0.10 \mathrm{~b}$ & $3.66 \pm \pm 0.18 \mathrm{ab}$ & $0.076 \pm \pm 0.004 \mathrm{bc}$ \\
\hline
\end{tabular}

The means followed by different letters in the same column are significantly different (Tukey test, $P<0.05$ ). ECl, efficiency of conversion of ingested food; ECD, efficiency of conversion of digested food; $R C R$, relative consumption rate; $R G R$, relative growth rate.

TABLE 6 | The mean ( \pm SE) energy reserves of fourth-instar larvae of Ectomyelois ceratoniae reared on various pomegranate cultivars.

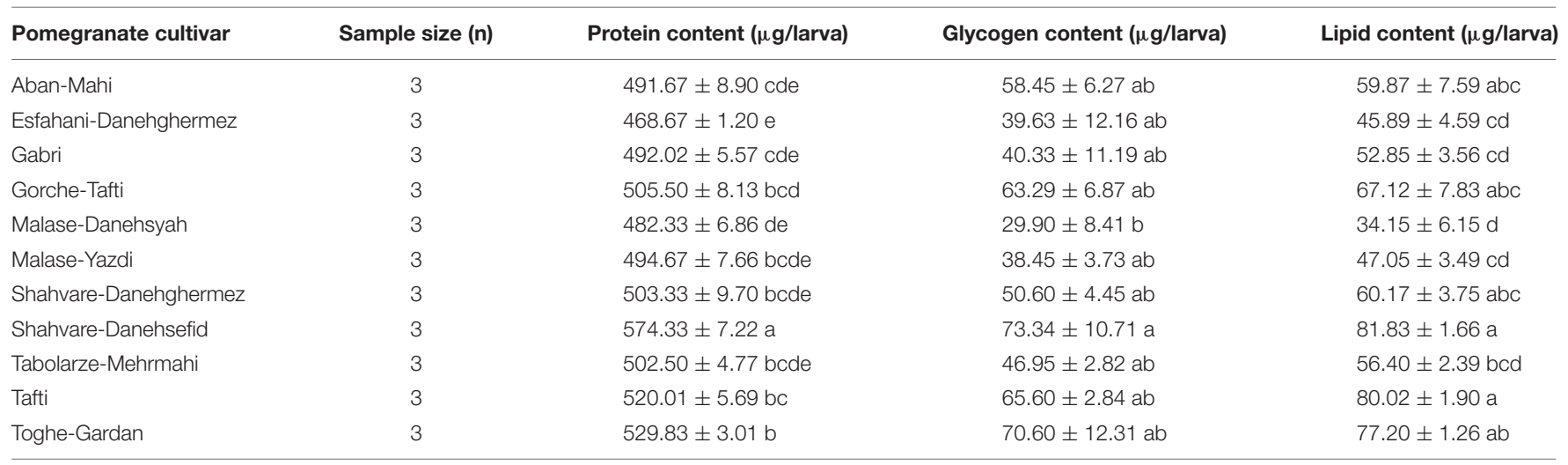

Mean values in a column followed by different lowercase letters are significantly different on the basis of ANOVA with Tukey test $(P<0.05)$. 
content $(F=3.16 ; \mathrm{df}=10,32 ; P=0.0118)$. Larvae fed on the Shahvare-Danesefid and Tafti cultivars showed the highest lipid content $(F=11.07$;f $=10,32 ; P<0.0001)$ while the lowest value was observed for larvae reared on the Malase-Danesyah cultivar (Table 6).

A dendrogram based on population growth parameters, nutritional indices, and energy reserves of $E$. ceratoniae on various pomegranate cultivars is shown in Figure 2 . The dendrogram revealed two clusters labeled A (including subclusters A1 and A2) and B. Different pomegranate cultivars tested were grouped within each cluster according to the E. ceratoniae criteria. Cluster B included Shahvare-Danesefid; sub-cluster A2 consisted of Esfahani-Daneghermez and Malase-Danesyah and other cultivars were in sub-cluster A1.

\section{Biochemical Traits of Pomegranate Cultivars}

Concentrations of the major anthocyanins measured in the pomegranate cultivars that we examined are listed in Table 7.
Six compounds, namely cyanidin 3-glucoside $(0.48-11.91 \mathrm{mg} / \mathrm{L})$, cyanidin 3,5-diglucoside (1.90-54.47 mg/L), delphinidin 3glucoside $(0.78-4.28 \mathrm{mg} / \mathrm{L})$, delphinidin 3,5-diglucoside $(0.072$ $40.59 \mathrm{mg} / \mathrm{L})$, pelargonidin 3-glucoside $(0.118-0.55 \mathrm{mg} / \mathrm{L})$, and pelargonidin 3,5-diglucoside (0.37-3.52 mg/L), were detected as major anthocyanin constituents from various pomegranate juice cultivars. There were significant differences among various pomegranate cultivars for all the detected anthocyanin compounds (Table 7). Esfahani-Daneghermez cultivar showed the highest value of cyanidin 3-glucoside $(F=710.64$; df $=10$, 32; $P<0.0001)$ compound compared with other cultivars. The cyanidin 3,5-diglucoside $(F=979.90 ; \mathrm{df}=10,32 ; P<0.0001)$ was significantly higher in Esfahani-Daneghermez. Also, the highest value of delphinidin 3-glucoside $(F=473.38$; $\mathrm{df}=10$, 32; $P<0.0001)$, delphinidin 3,5-diglucoside $(F=24.31 ; \mathrm{df}=10$, 32; $P<0.0001)$, pelargonidin 3-glucoside $(F=52.35$; $\mathrm{df}=10$, 32; $P<0.0001)$ and pelargonidin 3,5-diglucoside $(F=12.74$; $\mathrm{df}=10,32 ; P<0.0001)$ compounds were measured in EsfahaniDaneghermez (Table 7).

\section{Dendrogram using Ward Method}

C A S E Label

Aban-Mahi Tabolarzi Sh-Daneghermez Tafti Gorche-Tafti Toghe-Gardan Gabri

Malase-Yazdi Es-Daneghermez Malase-Danesya

Sh-Danesefid
Rescaled Distance Cluster Combine
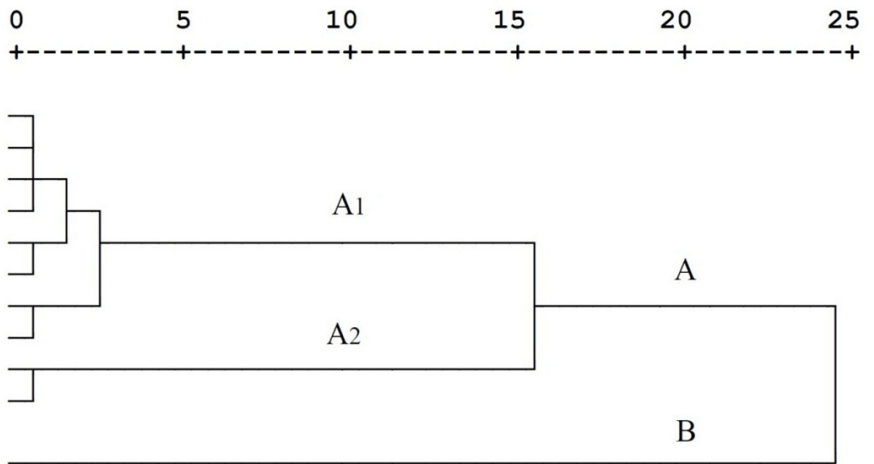

FIGURE 2 | Dendrogram of different pomegranate cultivars based on life table parameters, nutritional indices and energy reserves of Ectomyelois ceratoniae reared on various pomegranate cultivars.

TABLE 7 | The means ( \pm SE) major anthocyanins constituents (mg/L) of various pomegranate cultivars.

\begin{tabular}{|c|c|c|c|c|c|c|c|}
\hline $\begin{array}{l}\text { Pomegranate } \\
\text { cultivar }\end{array}$ & $\begin{array}{l}\text { Sample } \\
\text { size (n) }\end{array}$ & $\begin{array}{c}\text { Cyanidin } \\
\text { 3-glucoside }\end{array}$ & $\begin{array}{c}\text { Cyanidin } \\
\text { 3,5-diglucoside }\end{array}$ & $\begin{array}{l}\text { Delphinidin } \\
\text { 3-glucoside }\end{array}$ & $\begin{array}{c}\text { Delphinidin } \\
\text { 3,5 diglucoside }\end{array}$ & $\begin{array}{l}\text { Pelargonidin } \\
\text { 3- glucoside }\end{array}$ & $\begin{array}{c}\text { Pelargonidin } \\
\text { 3,5- diglucoside }\end{array}$ \\
\hline Aban-Mahi & 3 & $2.13 \pm 0.05 d$ & $7.73 \pm 0.37 d$ & $1.19 \pm 0.02 \mathrm{e}$ & $1.38 \pm 0.40 c$ & $0.17 \pm 0.010 \mathrm{bcd}$ & $0.56 \pm 0.040 \mathrm{~d}$ \\
\hline Esfahani-Danehghermez & 3 & $11.91 \pm 0.04 \mathrm{a}$ & $54.47 \pm 1.47 \mathrm{a}$ & $4.28 \pm 0.09 a$ & $40.59 \pm 7.94 \mathrm{a}$ & $0.51 \pm 0.020 \mathrm{a}$ & $3.52 \pm 0.080 \mathrm{a}$ \\
\hline Gabri & 3 & $2.61 \pm 0.03 d$ & $13.36 \pm 0.24 c$ & $1.56 \pm 0.02 d$ & $2.61 \pm 0.07 \mathrm{bc}$ & $0.24 \pm 0.006 \mathrm{bc}$ & $1.17 \pm 0.020 \mathrm{bcd}$ \\
\hline Gorche-Tafti & 3 & $1.11 \pm 0.02 \mathrm{e}$ & $4.17 \pm 0.03$ ef & $0.95 \pm 0.00$ ef & $1.28 \pm 0.03 c$ & $0.13 \pm 0.001 \mathrm{~cd}$ & $0.43 \pm 0.020 \mathrm{~d}$ \\
\hline Malase-Danehsyah & 3 & $5.44 \pm 0.12 c$ & $39.83 \pm 0.96 b$ & $3.52 \pm 0.15 b$ & $2.01 \pm 0.57 b$ & $0.25 \pm 0.004 b$ & $2.36 \pm 0.090 \mathrm{ab}$ \\
\hline Malase-Yazdi & 3 & $9.94 \pm 0.24 b$ & $37.44 \pm 0.64 b$ & $3.16 \pm 0.04 c$ & $9.33 \pm 0.70 b$ & $0.55 \pm 0.070 \mathrm{a}$ & $2.92 \pm 0.280 \mathrm{a}$ \\
\hline Shahvare-Danehghermez & 3 & $0.48 \pm 0.06 \mathrm{e}$ & $6.02 \pm 0.17 \mathrm{de}$ & $1.06 \pm 0.03$ ef & $1.42 \pm 0.01 c$ & $0.15 \pm 0.002 \mathrm{bcd}$ & $1.14 \pm 0.010 \mathrm{bcd}$ \\
\hline Shahvare-Danehsefid & 3 & $0.86 \pm 0.01 \mathrm{e}$ & $3.39 \pm 0.04$ ef & $0.90 \pm 0.01 \mathrm{f}$ & $0.072 \pm 0.01 \mathrm{c}$ & $0.118 \pm 0.001 d$ & $0.37 \pm 0.002 \mathrm{~d}$ \\
\hline Tabolarze-Mehrmahi & 3 & $1.16 \pm 0.38 \mathrm{e}$ & $15.81 \pm 0.02 \mathrm{c}$ & $1.72 \pm 0.00 \mathrm{~d}$ & $0.197 \pm 0.05 c$ & $0.16 \pm 0.006 \mathrm{bcd}$ & $2.23 \pm 0.910 \mathrm{abc}$ \\
\hline Tafti & 3 & $0.64 \pm 0.13 \mathrm{e}$ & $1.90 \pm 0.07 f$ & $0.78 \pm 0.02 \mathrm{f}$ & $0.81 \pm 0.06 c$ & $0.119 \pm 0.001 d$ & $0.74 \pm 0.390 \mathrm{~cd}$ \\
\hline Toghe-Gardan & 3 & $0.83 \pm 0.01 \mathrm{e}$ & $3.61 \pm 0.13$ ef & $0.92 \pm 0.01$ ef & $0.89 \pm 0.04 c$ & $0.122 \pm 0.002 \mathrm{~d}$ & $0.37 \pm 0.010 d$ \\
\hline
\end{tabular}

Mean values in a column followed by different lowercase letters are significantly different on the basis of ANOVA with Tukey test (P < 0.05). 
Biochemical characteristics of tested pomegranate cultivars used for feeding of E. ceratoniae are given in Tables 8, 9. No significant differences were observed in total protein content $(F=1.10 ; \mathrm{df}=10,32 ; P=0.41)$ among the pomegranate cultivars. The carbohydrate content varied from $92.61 \mathrm{mg} / \mathrm{mL}$ in Esfahani-Daneghermez to $138.33 \mathrm{mg} / \mathrm{mL}$ in Shahvare-Danesefid cultivar $(F=16.22$; df $=10,32 ; P<0.0001)$. Furthermore, a higher content of condensed tannins was measured in Esfahani-Daneghermez and Shahvare-Daneghermez, whereas a lower content was detected in Shahvare-Danesefid and TogheGardan cultivars $(F=12.18 ; \mathrm{df}=10,32 ; P<0.0001)$ (Table 8). There was a significant difference for the total phenolic (TPC) $(F=45.22 ; \mathrm{df}=10,32 ; P<0.0001)$ and total monomeric anthocyanin pigment (TMAC) $(F=38.99$; $\mathrm{df}=10,32 ; P<0.0001)$ contents of different pomegranate cultivars. A higher value of TPC and TMAC was measured in Esfahani-Daneghermez cultivar and the lowest value of TMAC was detected in Shahvare-Danesefid and Tafti cultivars. The highest flavonoid content was measured in EsfahaniDaneghermez, whereas the lowest content was observed in the
Shahvare-Danesefid and Toghe-Gardan cultivars $(F=44.70$; $\mathrm{df}=10,32 ; P<0.0001)$ (Table 8).

Antioxidant activity (AA\%) varied from 49.17 in Tafti to 60.13 (AA\%) in the Esfahani-Daneghermez cultivar $(F=8.30$; $\mathrm{df}=10,32 ; P<0.0001)$. Moreover, the highest $\mathrm{pH}$ value was observed in the Shahvare-Danesefid cultivar while the lowest value was in the Malase-Danesyah cultivar $(F=34.32$; $\mathrm{df}=10,32$; $P<0.0001)$. The highest total titrable acidity value was obtained for the Malase-Danesyah cultivar, whereas the lowest value was seen for the Shahvare-Danesefid cultivar $(F=24.37$; $\mathrm{df}=10,32$; $P<0.0001)$. The percentage of juice showed limited variation, ranging from 50.15 to 61.32 for the pomegranate cultivars under investigation $(F=2.66 ; \mathrm{df}=10,32 ; P=0.0265)$. The soluble solids content was lowest in the Tabolarze-Mehrmahi cultivar $(F=2.42$; $\mathrm{df}=10,32 ; P=0.040)$ (Table 9).

\section{Correlation Analysis}

Tables 10, 11 show coefficients obtained for analyses of correlation between life table parameters and physiological characteristics of E. ceratoniae fed on different cultivars, on

TABLE 8 | Some biochemical characteristics of tested various pomegranate juice cultivars.

\begin{tabular}{|c|c|c|c|c|c|c|c|}
\hline $\begin{array}{l}\text { Pomegranate } \\
\text { cultivar }\end{array}$ & $\begin{array}{l}\text { Sample } \\
\text { size (n) }\end{array}$ & $\begin{array}{l}\text { Total Protein } \\
(\mathrm{mg} / \mathrm{mL})\end{array}$ & $\begin{array}{c}\text { Carbohydrate } \\
\text { content } \\
\text { (mg/mL) }\end{array}$ & $\begin{array}{c}\text { CT } \\
(\mathrm{mg} / \mathrm{mL})\end{array}$ & $\begin{array}{c}\text { TPC } \\
(\mathrm{mg} / 100 \mathrm{~mL})\end{array}$ & $\begin{array}{l}\text { TMAC } \\
\text { (mg/L) }\end{array}$ & $\begin{array}{l}\text { Flavonoid } \\
\text { (mg/mL) }\end{array}$ \\
\hline Aban-Mahi & 3 & $0.139 \pm 0.004 \mathrm{a}$ & $102.78 \pm 4.99 \mathrm{bc}$ & $20.01 \pm 1.05 \mathrm{abcd}$ & $277.35 \pm 9.33 \mathrm{abc}$ & $138.07 \pm 8.09$ cde & $98.37 \pm 6.15 b$ \\
\hline Esfahani-Danehghermez & 3 & $0.133 \pm 0.003 \mathrm{a}$ & $92.61 \pm 5.61 \mathrm{c}$ & $23.55 \pm 0.58 \mathrm{a}$ & $308.61 \pm 1.21 \mathrm{a}$ & $244.52 \pm 5.81 \mathrm{a}$ & $132.44 \pm 11.37 \mathrm{a}$ \\
\hline Gabri & 3 & $0.132 \pm 0.002 \mathrm{a}$ & $97.06 \pm 3.19 \mathrm{bc}$ & $21.08 \pm 1.14 \mathrm{abc}$ & $246.68 \pm 11.13 \mathrm{bcd}$ & $152.24 \pm 8.50 \mathrm{bcd}$ & $90.84 \pm 0.83 b$ \\
\hline Gorche-Tafti & 3 & $0.136 \pm 0.005 a$ & $131.45 \pm 0.89 a$ & $16.21 \pm 1.39 \mathrm{cde}$ & $165.35 \pm 6.96$ ef & $99.69 \pm 13.72 \mathrm{efg}$ & $40.44 \pm 3.46 \mathrm{~cd}$ \\
\hline Malase-Danehsyah & 3 & $0.130 \pm 0.002 \mathrm{a}$ & $94.39 \pm 4.36 \mathrm{bc}$ & $21.55 \pm 0.57 \mathrm{ab}$ & $294.68 \pm 5.77 \mathrm{ab}$ & $172.93 \pm 8.46 \mathrm{bc}$ & $108.04 \pm 4.45 a b$ \\
\hline Malase-Yazdi & 3 & $0.136 \pm 0.002 \mathrm{a}$ & $95.44 \pm 6.65 \mathrm{bc}$ & $19.95 \pm 0.74 \mathrm{abcd}$ & $259.68 \pm 1.73 \mathrm{abc}$ & $181.20 \pm 4.69 b$ & $98.77 \pm 3.48 b$ \\
\hline Shahvare-Danehghermez & 3 & $0.134 \pm 0.001 \mathrm{a}$ & $117.67 \pm 0.92 \mathrm{ab}$ & $23.15 \pm 0.71 \mathrm{a}$ & $202.68 \pm 25.16 \mathrm{de}$ & $169.73 \pm 5.37$ bcd & $63.11 \pm 6.36 \mathrm{c}$ \\
\hline Shahvare-Danehsefid & 3 & $0.138 \pm 0.002 \mathrm{a}$ & $138.33 \pm 0.73 \mathrm{a}$ & $14.01 \pm 0.64 \mathrm{e}$ & $131.35 \pm 4.37 f$ & $90.78 \pm 7.92 \mathrm{~g}$ & $27.11 \pm 3.53 d$ \\
\hline Tabolarze-Mehrmahi & 3 & $0.131 \pm 0.002 \mathrm{a}$ & $99.61 \pm 5.24 \mathrm{bc}$ & $18.01 \pm 1.80$ bcde & $236.68 \pm 9.02 \mathrm{~cd}$ & $132.31 \pm 3.09$ def & $93.11 \pm 3.71 b$ \\
\hline Tafti & 3 & $0.134 \pm 0.001 \mathrm{a}$ & $134.61 \pm 1.02 \mathrm{a}$ & $16.01 \pm 0.70 \mathrm{de}$ & $144.68 \pm 5.29 f$ & $91.38 \pm 8.23 \mathrm{~g}$ & $37.77 \pm 4.66 \mathrm{~cd}$ \\
\hline Toghe-Gardan & 3 & $0.133 \pm 0.004 \mathrm{a}$ & $135.83 \pm 1.11 \mathrm{a}$ & $14.28 \pm 0.46 \mathrm{e}$ & $130.68 \pm 3.46 f$ & $95.83 \pm 5.37 \mathrm{fg}$ & $32.44 \pm 4.16 d$ \\
\hline
\end{tabular}

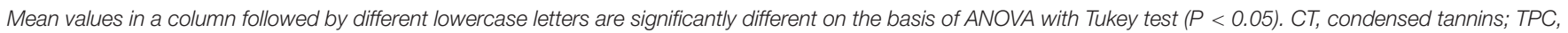
total phenolic content; TMAC, total monomeric anthocyanin pigment content.

TABLE 9 | Some biochemical characteristics of tested various pomegranate juice cultivars.

\begin{tabular}{|c|c|c|c|c|c|c|}
\hline Pomegranate cultivar & Sample size (n) & DPPH (inhibition\%) & $\mathrm{pH}$ & $\mathrm{TA}(\mathrm{g} / \mathrm{L})$ & Juice (\%) & SSC ( ${ }^{\circ}$ Brix) \\
\hline Aban-Mahi & 3 & $51.71 \pm 0.58 \mathrm{~cd}$ & $3.55 \pm 0.08$ de & $2.33 \pm 0.07 \mathrm{bc}$ & $51.13 \pm 1.65 b$ & $16.67 \pm 0.67 \mathrm{ab}$ \\
\hline Esfahani-Danehghermez & 3 & $60.13 \pm 0.96 a$ & $3.30 \pm 0.08$ ef & $2.73 \pm 0.07 \mathrm{abc}$ & $53.42 \pm 3.55 b$ & $17.01 \pm 0.58 \mathrm{a}$ \\
\hline Gabri & 3 & $57.80 \pm 2.39 \mathrm{abc}$ & $3.38 \pm 0.05$ ef & $2.79 \pm 0.23 a b$ & $57.04 \pm 2.17 \mathrm{ab}$ & $17.17 \pm 0.44 \mathrm{a}$ \\
\hline Gorche-Tafti & 3 & $50.83 \pm 0.57 \mathrm{~d}$ & $4.07 \pm 0.09 \mathrm{ab}$ & $1.33 \pm 0.13$ ef & $61.18 \pm 1.08 \mathrm{a}$ & $15.33 \pm 0.34 \mathrm{bc}$ \\
\hline Malase-Danehsyah & 3 & $58.48 \pm 2.54 \mathrm{ab}$ & $3.21 \pm 0.05 f$ & $2.99 \pm 0.11 \mathrm{a}$ & $51.68 \pm 2.39 b$ & $17.33 \pm 0.67 \mathrm{a}$ \\
\hline Malase-Yazdi & 3 & $54.47 \pm 0.51 \mathrm{abcd}$ & $3.28 \pm 0.04$ ef & $2.87 \pm 0.18 \mathrm{ab}$ & $56.50 \pm 3.29 a b$ & $16.83 \pm 0.44 \mathrm{ab}$ \\
\hline Shahvare-Danehghermez & 3 & $52.23 \pm 1.13 \mathrm{bcd}$ & $3.73 \pm 0.08 \mathrm{~cd}$ & $2.13 \pm 0.13 \mathrm{~cd}$ & $55.80 \pm 1.38 \mathrm{ab}$ & $16.33 \pm 0.33 \mathrm{abc}$ \\
\hline Shahvare-Danehsefid & 3 & $50.94 \pm 0.95 d$ & $4.15 \pm 0.04 \mathrm{a}$ & $0.93 \pm 0.13 f$ & $61.32 \pm 1.02 \mathrm{a}$ & $16.01 \pm 0.58 \mathrm{abc}$ \\
\hline Tabolarze-Mehrmahi & 3 & $54.48 \pm 0.51 \mathrm{abcd}$ & $3.83 \pm 0.05 \mathrm{bcd}$ & $1.60 \pm 0.11 \mathrm{de}$ & $50.15 \pm 1.78 b$ & $15.01 \pm 0.58 \mathrm{c}$ \\
\hline Tafti & 3 & $49.17 \pm 1.20 \mathrm{~d}$ & $4.01 \pm 0.07 \mathrm{abc}$ & $1.27 \pm 0.06$ ef & $54.82 \pm 1.11 \mathrm{ab}$ & $17.33 \pm 0.67 \mathrm{a}$ \\
\hline Toghe-Gardan & 3 & $49.94 \pm 0.67 \mathrm{~d}$ & $3.96 \pm 0.04 a b c$ & $1.40 \pm 0.11$ ef & $52.38 \pm 3.77 b$ & $17.5 \pm 0.51 \mathrm{a}$ \\
\hline
\end{tabular}

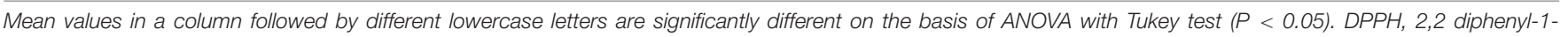
picrylhydrazyl; TA, total titrable acidity; SSC, soluble solids content. 
the one hand, and different biochemical traits of the various pomegranate cultivars tested, on the other hand; significant positive or negative correlations were observed (Tables 10, 11).

These analyses revealed high positive correlation between developmental time and contents of all major anthocyanin compounds of pomegranate cultivars, while a significant negative correlation was observed between $R_{0}$ and $r_{m}$, and all major anthocyanin contents (Table 10).

Fecundity and pupal weight, as well as the nutritional indices ECI and RGR, were also negatively correlated with contents of all major anthocyanins, whereas RCR was positively correlated with these same variables (Table 10).

The life history variables and physiological characteristics of E. ceratoniae listed in Table $\mathbf{1 1}$ were not significantly correlated with total protein contents of the various pomegranate cultivars. However, significant positive or negative correlations were observed for life history variables and physiological characteristics with carbohydrate and condensed tannins of pomegranate cultivars. Very high positive correlations were observed between the carbohydrate content of the cultivars and E. ceratoniae fecundity, pupal weight, protein content of larvae, $R_{0}$ and $r_{m}$; developmental time, on the other hand, was negatively correlated with this biochemical trait of pomegranate cultivars. Moreover, a significant negative correlation was observed between condensed tannins of various pomegranate cultivars and
E. ceratoniae fecundity, pupal weight, protein content of larva, $R_{0}$, $r_{m}$, ECI and RGR (Table 11).

Significant correlations were observed for life history variables and physiological characteristics of E. ceratoniae with total phenolic content, total monomeric anthocyanin pigment content, and DPPH of pomegranate cultivars. Specifically, fecundity, pupal weight, protein content of larva, $R_{0}, r_{m}$, ECI and RGR all displayed a significant negative correlation with total phenolic content, total monomeric anthocyanin pigment content, DPPH of pomegranate cultivars; conversely, developmental time and RCR were positively correlated with these biochemical traits of pomegranate cultivars (Table 11).

\section{DISCUSSION}

Research on plant-herbivore interactions is one of the most important and multidisciplinary undertakings in plant biology, involving various disciplines to describe chemical and ecological processes influencing the outcome of plantherbivore interactions (War et al., 2012). The results of the present study indicated that E. ceratoniae is able to complete its development, survive, and reproduce on all pomegranate cultivars examined; however, its growth rates significantly varied among the tested cultivars. The present research

TABLE 10 | Correlation coefficients (r) of some life history parameters and physiological characteristics of Ectomyelois ceratoniae fed on different pomegranate cultivars with major anthocyanins constituents of various pomegranate cultivars.

\begin{tabular}{|c|c|c|c|c|c|c|}
\hline Parameter & $\begin{array}{l}\text { Cyanidin } \\
\text { 3-glucoside }\end{array}$ & $\begin{array}{c}\text { Cyanidin } \\
\text { 3,5-diglucoside }\end{array}$ & $\begin{array}{l}\text { Delphinidin } \\
\text { 3-glucoside }\end{array}$ & $\begin{array}{c}\text { Delphinidin } \\
\text { 3,5-diglucoside }\end{array}$ & $\begin{array}{l}\text { Pelargonidin } \\
\text { 3- glucoside }\end{array}$ & $\begin{array}{l}\text { Pelargonidin } \\
\text { 3,5-diglucoside }\end{array}$ \\
\hline Development time & $0.665(0.026)$ & $0.813(0.002)$ & $0.819(0.002)$ & $0.606(0.048)$ & $0.593(0.05)$ & $0.758(0.007)$ \\
\hline Weight of pupa & $-0.774(0.005)$ & $-0.890(0.000)$ & $-0.894(0.000)$ & $-0.555(0.077)$ & $-0.751(0.008)$ & $-0.888(0.000)$ \\
\hline Protein content of larva & $-0.590(0.056)$ & $-0.664(0.026)$ & $-0.662(0.026)$ & $-0.503(0.115)$ & $-0.572(0.066)$ & $-0.660(0.027)$ \\
\hline$R_{0}$ & $-0.790(0.004)$ & $-0.876(0.000)$ & $-0.872(0.000)$ & $-0.697(0.017)$ & $-0.752(0.008)$ & $-0.886(0.000)$ \\
\hline $\mathrm{RCR}$ & $0.510(0.109)$ & $0.659(0.027)$ & $0.655(0.029)$ & $0.420(0.198)$ & $0.523(0.099)$ & $0.796(0.003)$ \\
\hline RGR & $-0.534(0.090)$ & $-0.619(0.042)$ & $-0.620(0.042)$ & $-0.371(0.261)$ & $-0.569(0.068)$ & $-0.664(0.026)$ \\
\hline
\end{tabular}

Correlations were evaluated based on Pearson's correlation test $(P<0.05)$. The number in parenthesis is $P_{\text {value. }}$.

TABLE 11 | Correlation coefficients ( $r$ ) of some life history parameters and physiological characteristics of Ectomyelois ceratoniae fed on different pomegranate cultivars with biochemical traits of various pomegranate cultivars.

\begin{tabular}{|c|c|c|c|c|c|c|}
\hline Parameter & Total pProtein & Carbohydrate & CT & TPC & TMAC & DPPH \\
\hline Development time & $-0.517(0.103)$ & $-0.832(0.001)$ & $0.886(0.000)$ & $0.883(0.000)$ & $0.876(0.000)$ & $0.912(0.000)$ \\
\hline Fecundity & $0.543(0.084)$ & $0.893(0.000)$ & $-0.794(0.004)$ & $-0.884(0.000)$ & $-0.841(0.001)$ & $-0.824(0.002)$ \\
\hline Weight of pupa & $0.467(0.147)$ & $0.873(0.000)$ & $-0.846(0.001)$ & $-0.883(0.000)$ & $-0.888(0.000)$ & $-0.870(0.001)$ \\
\hline Protein content of larva & $0.409(0.212)$ & $0.818(0.002)$ & $-0.821(0.002)$ & $-0.853(0.001)$ & $-0.770(0.006)$ & $-0.695(0.018)$ \\
\hline$R_{0}$ & $0.490(0.126)$ & $0.867(0.001)$ & $-0.832(0.001)$ & $-0.890(0.000)$ & $-0.903(0.000)$ & $-0.839(0.001)$ \\
\hline$r_{m}$ & $0.511(0.108)$ & $0.899(0.000)$ & $-0.881(0.000)$ & $-0.916(0.000)$ & $-0.908(0.000)$ & $-0.880(0.000)$ \\
\hline $\mathrm{ECl}$ & $0.580(0.061)$ & $0.849(0.001)$ & $-0.834(0.001)$ & $-0.801(0.003)$ & $-0.803(0.003)$ & $-0.739(0.009)$ \\
\hline $\mathrm{RCR}$ & $-0.504(0.114)$ & $-0.856(0.001)$ & $0.727(0.011)$ & $0.792(0.004)$ & $0.743(0.009)$ & $0.743(0.009)$ \\
\hline RGR & $0.590(0.056)$ & $0.779(0.005)$ & $-0.802(0.003)$ & $-0.732(0.010)$ & $-0.751(0.008)$ & $-0.662(0.026)$ \\
\hline
\end{tabular}

Correlations were evaluated based on Pearson's correlation test $(P<0.05)$. The number in parenthesis is $P_{\text {value. }}$ 
demonstrates the existence of interactions between biochemical characteristics of various pomegranate cultivars with growth rate, life table parameters, and nutritional indices of this pest. There are complex interactions of macronutrients with other dietary characteristics influencing lifespan and reproduction rate (Coskun et al., 2005; Chen et al., 2009). Primary plant metabolites, including nitrogen, protein, and carbohydrates have been shown to strongly affect the feeding and growth of insect herbivores (Soufbaf et al., 2012; Golizadeh and Abedi, 2017); however, less attention has been given to secondary plant metabolites and their effects on insect performance (Harvey, 2005; Ode, 2006; Mardani-Talaee et al., 2016).

In the present research, E. ceratoniae developed more slowly on Esfahani-Daneghermez and Malase-Danesyah cultivars, suggesting that the nutritional quality of these cultivars is less suitable for the feeding of larvae. It has been proposed that low nutritive quality of host diet is a possible measure offering resistance against insect herbivores (War et al., 2012; Akandeh et al., 2016). Variations in the duration of immature stages of $E$. ceratoniae might be attributed to differences in macronutrients and biochemical traits of the tested pomegranate cultivars. The shortest development time of E. ceratoniae on Shahvare-Danesefid cultivar may be explained by the higher carbohydrate value in this cultivar. Moreover, the secondary metabolites could be another factor affecting development time (Soufbaf et al., 2012; Nouri-Ganbalani et al., 2018). The content of major anthocyanin compounds and other secondary metabolites in Shahvare-Danesefid cultivar was lower than that of other tested pomegranate cultivars. There is a negative correlation between the development time of E. ceratoniae and macronutrients (especially carbohydrate) of pomegranate cultivars. Development time was positively correlated with major anthocyanin constituents, condensed tannins, total phenolic content, total monomeric anthocyanin pigment content, flavonoid, DPPH, and total titrable acidity of pomegranate cultivars, suggesting that pest development rate is negatively affected by respective metabolites and that these factors play a decisive role in the fitness of this insect. The longer development time of E. ceratoniae on EsfahaniDaneghermez cultivar may be due to higher levels of secondary metabolites $\mathrm{n}$ this cultivar. The range of larval and pupal periods of E. ceratoniae on tested cultivars is somewhat in agreement with the findings of Norouzi et al. (2008), Zare et al. (2013), and Mortazavi et al. (2016).

It has been reported that body weight is associated with the quality and quantity of food, which is one of the main biological indices of insect population dynamics (Li et al., 2004). The lower pupal weight of carob moths on Malase-Danesyah and Esfahani-Daneghermez cultivars indicated that the larvae fed on these cultivars did more poorly than on the other cultivars. The range of pupal weight for E. ceratoniae in the current study was greater than that reported by Mortazavi et al. (2016). The variations in nutritional quality or secondary compounds among the pomegranate cultivars can influence the larval and pupal development and can be reflected in the pupal weight of E. ceratoniae. The reduced body weight of this pest on cultivars Malase-Danesyah and Esfahani-Daneghermez might be attributed to the lower carbohydrate content and higher contents of secondary metabolites in these cultivars.

In this study, adults reared as larvae on the ShahvareDanesefid and Toghe-Gardan cultivars presented higher fecundity and longevity, indicating suitability of these cultivars for reproduction of this pest. Regarding the larval and pupal weights, it is evident that the fecundity values can be correlated with the weights of larvae and pupae on the respective cultivars (Golizadeh and Abedi, 2016). This is illustrated by the present study, in which it was found that the development times of E. ceratoniae fed on pomegranate cultivars were positively correlated with levels of the major anthocyanin constituents and secondary compounds, suggesting that phytochemical metabolites play a negative role in the growth of this insect. In this study, the range of male and female longevities of E. ceratoniae was close to those reported earlier for E. ceratoniae reared on three pomegranate cultivars, including Malase-danesyah, Gabri, and Shahvar (Zare et al., 2013).

The results of the present investigation revealed that pomegranate cultivar is a major factor influencing life table parameters of E. ceratoniae so that its best and worst performances were observed on the Shahvare-Danesefid and Esfahani-Daneghermez cultivars, respectively. The reduced $R_{0}$, $G R R, r_{m}$ and $\lambda$ of this pest on Esfahani-Daneghermez cultivar might be attributed to the positive correlation of these factors with primary metabolites as well as negative correlation with secondary metabolites of tested cultivars. Normally, higher $r_{m}$ is related to shorter developmental time, lower mortality, and greater fecundity, which is true for E. ceratoniae reared on Shahvare-Danesefid. The range of $r_{m}$ values of E. ceratoniae on various pomegranate cultivars tested in the present study was smaller than that reported by Norouzi et al. (2008), Zare et al. (2013), and Mortazavi et al. (2015). Such discrepancy might be attributable to either genetic differences in pest populations or variations in the experimental conditions and cultivars used for feeding of this pest.

The lower food consumption by E. ceratoniae on EsfahaniDaneghermez is likely attributable to the poor nutritional quality of this cultivar. The higher ECI value for E. ceratoniae on the Shahvare-Danesefid and Gorche-Tafti cultivars indicated that the larvae were able to convert digested food to body mass and that the weights of larvae improved on these cultivars. Furthermore, a significant correlation between ECI with starch and carbohydrate content indicated that larvae efficiently utilized carbohydrate for better growth. In contrast, the larvae reared on EsfahaniDaneghermez and Malase-Danesyah cultivars showed a lower ability to convert the ingested food into biomass, which led to the reduction in food consumption and weight of larvae (Nathan et al., 2005). The highest RCR value of E. ceratoniae on Esfahani-Daneghermez and Tabolarze-Mehrmahi could be due to the higher level of secondary compounds in these cultivars. Moreover, the variation in RGR and whole-body protein contents of populations reared on different pomegranate cultivars may have resulted from differences in primary plant metabolites among the cultivars.

In the present study, cluster analysis with respect to life table parameters, nutritional indices, and energy reserves of 
E. ceratoniae on tested pomegranate cultivars revealed two separate main clusters. Shahvare-Danesefid cultivar is the only member in cluster B as the most susceptible cultivar. The grouping within each class might be due to a high level of physiological similarity of pomegranate cultivars. Cluster A can be divided into two distinct sub-clusters (A1 and A2). Sub-cluster A2 consisted of Esfahani-Daneghermez and Malase-Danesyah (most relatively unsuitable cultivars), and other cultivars were grouped in sub-cluster A1 based on their similarity in primary and secondary metabolite contents (partially unsuitable cultivars).

\section{CONCLUSION}

Results of the present study point to the apparent adaptability of E. ceratoniae to feeding on various pomegranate cultivars, albeit with different degrees of success. Our results indicate that insects fed on the Shahvare-Danesefid cultivar displayed the fastest development and highest adult fecundity and longevity, immature survival rate and nutritional performance, apparently as a consequence of the higher primary metabolite and lower secondary metabolite contents of the host plant. Therefore, this cultivar was the most suitable (least resistant) cultivar for E. ceratoniae, among those tested here. Moreover, the Esfahani-Daneghermez cultivar was the least suitable (most resistant) pomegranate cultivar for E. ceratoniae, apparently as a

\section{REFERENCES}

Akandeh, M., Soufbaf, M., Kocheili, F., and Rasekh, A. (2016). Gamma irradiation on canola seeds affects herbivore-plant and host-parasitoid interactions. Neotrop. Entomol. 46, 256-263. doi: 10.1007/s13744-0160460-4

Akhavan, H., Barzegar, M., Weidlich, H., and Zimmermann, B. F. (2015). Phenolic compounds and antioxidant activity of juices from ten iranian pomegranate cultivars depend on extraction. J. Chem. N.Y. 2015, 1-7. doi: 10.1155/2015/ 907101

Alighourchi, H., Barzegar, M., and Abbasi, S. (2008). Anthocyanins characterization of 15 iranian pomegranate (Punica granatum L.) varieties and their variation after cold storage and pasteurization. Eur. Food Res. Technol. 227, 881-887. doi: 10.1007/s00217-007-0799-1

Alighourchi, H. R., Barzegar, M., Sahari, M. A., and Abbasi, S. (2013). Effect of sonication on anthocyanins, total phenolic content, and antioxidant capacity of pomegranate juices. Int. Food Res. J. 20, 1703-1709.

Ashtari, M., Khademia, O., Soufbaf, M., Afsharmanesh, H., and AskariSarcheshmeh, M. A. (2019). Effect of gamma irradiation on antioxidants, microbiological properties and shelf life of pomegranate arils cv. 'Malas Saveh'. Sci. Hortic. 244, 365-371. doi: 10.1016/j.scienta.2018.09.067

Bemani, M., Izadi, H., Mahdian, K., Khani, A., and Samih, M. A. (2012). Study on the physiology of diapause, cold hardiness and supercooling point of overwintering pupae of the pistachio fruit hull borer. Arimania comaroffi. J. Insect Physiol. 58, 897-902. doi: 10.1016/j.jinsphys. 2012.04.003

Bradford, M. M. (1976). A rapid and sensitive method for the quantitation of microgram quantities of protein utilizing the principle of protein-dye binding. Anal. Biochem. 72, 248-254. doi: 10.1016/0003-2697(76)90527-3

Chen, Y., Ni, X., and Buntin, G. D. (2009). Physiological, nutritional, and biochemical bases of corn resistance to foliage-feeding fall armyworm. J. Chem. Ecol. 35, 297-306. doi: 10.1007/s10886-009-9600-1 consequence of the higher secondary metabolite contents of the host plant. Consequently, Esfahani-Daneghermez was designated as the most unsuitable cultivar among those tested in the present work; we recommend that it be grown in areas where damage by E. ceratoniae is typically high, with the view to protecting or at least delaying infestation of pomegranate by this pest.

\section{AUTHOR CONTRIBUTIONS}

All authors read and approved the manuscript. This research is a part of Ph.D. thesis of ZA. AG as supervisor and ZA proposed the research subject and wrote the manuscript. ZA conducted the experiments. MS, $\mathrm{MH}, \mathrm{AJ}-\mathrm{N}$, and $\mathrm{H}-\mathrm{RA}$ participated in the data analysis and acted as advisors.

\section{FUNDING}

This study was funded by the University of Mohaghegh Ardabili and Iran National Science Foundation (INSF).

\section{ACKNOWLEDGMENTS}

This work received financial support from the University of Mohaghegh Ardabili and Iran National Science Foundation (INSF) which is greatly appreciated.

Chi, H. (1988). Life-table analysis incorporating both sexes and variable development rates among individuals. Environ. Entomol. 17, 26-34. doi: 10. 1093/ee/17.1.26

Chi, H. (2016). TWOSEX-MSChart: A Computer Program for the Age-Stage, TwoSex Life Table Analysis. Available at: http://140.120.197.173/Ecology/Download/ TWOSEX-MSchart.zip (accessed November 20, 2017).

Chi, H., and Liu, H. (1985). Two new methods for the study of insect population ecology. Bull. Inst. Zool. Academia Sinica 24, 225-240.

Chi, H., and Su, H. Y. (2006). Age-stage, two-sex life tables of Aphidius gifuensis (Ashmead) (Hymenoptera: Braconidae) and its host Myzus persicae (Sulzer) (Homoptera: Aphididae) with mathematical proof of the relationship between female fecundity and the net reproductive rate. Environ. Entomol. 35, 10-21. doi: 10.1603/0046-225X-35.1.10

Coskun, M., Ozalp, P., Sulanc, M., and Emre, I. (2005). Effects of various diets on the oviposition and sex ratio of Pimpla turionellae L. Int. J. Agric. Biol. 7, $129-132$.

Du, C. T., Wang, P. L., and Francis, F. J. (1975). Anthocyanins of pomegranate, Punica granatum. J. Food Sci. 40, 417-418. doi: 10.1111/j.1365-2621.1975. tb02217.x

Fischer, U. A., Carle, R., and Kammerer, D. R. (2011). Identification and quantification of phenolic compounds from pomegranate (Punica granatum L.) peel, mesocarp, aril and differently produced juices by HPLC-DAD-ESI/MSn. Food Chem. 127, 807-821. doi: 10.1016/j. foodchem

Golizadeh, A., and Abedi, Z. (2016). Comparative performance of the Khapra beetle, Trogoderma granarium Everts (Coleoptera: Dermestidae) on various wheat cultivars. J. Stored Prod. Res. 69, 159-165. doi: 10.1016/j.jspr.2016. 08.003

Golizadeh, A., and Abedi, Z. (2017). Feeding performance and life table parameters of Khapra beetle, Trogoderma granarium Everts (Coleoptera: Dermestidae) on various barley cultivars. Bull. Entomol. Res. 14, 1-10. doi: 10.1017/ S0007485317000207 
Golizadeh, A., Kamali, K., Fathipour, Y., and Abbasipour, H. (2009). Life table of the diamondback moth, Plutella xylostella (L.) (Lepidoptera: Plutellidae) on five cultivated brassicaceous host plants. J. Agr. Sci. Tech-Iran. 11, $115-124$.

Gvozdenac, S. M., Prvulovi, D. M., Radovanovi, M. N., Ovuka, S., Mikli, V. J., Canski, J. M. A., et al. (2018). Life history of Plodia interpunctella Hübner on sunflower seeds: effects of seed qualitative traits and the initial seed damage. J. Stored Prod. Res. 79, 89-97. doi: 10.1016/j.jspr.2018. 08.003

Harvey, J. A. (2005). Factors affecting the evolution of development strategies in parasitoid wasps: the importance of functional constraints and incorporating complexity. Entomol. Exp. Appl. 117, 1-13. doi: 10.1111/j.1570-7458.2005. 00348.x

Harvey, J. A., Gols, R., Wagenaar, R., and Bezemer, T. M. (2007). Development of an insect herbivore and its pupal parasitoid reflect differences in direct plant defense. J. Chem. Ecol. 33, 1556-1569. doi: 10.1007/s10886-0079323-0

Jia, Z., Tang, M., and Wu, J. (1999). The determination of flavonoid contents in mulberry and their scavenging effects on superoxide radicals. Food Chem. 64, 555-559. doi: 10.1016/S0308-8146(98)00102-2

Karimi-Pormehr, M. S., Borzoui, E., Naseri, B., Rafiee Dastjerdi, H., and Mansouri, S. M. (2018). Two-sex life table analysis and digestive physiology of Sitotroga cerealella (Olivier) (Lepidoptera: Gelechiidae) on different barley cultivars. J. Stored Prod. Res. 75, 64-71. doi: 10.1016/j.jspr.2017. 10.005

Kishani-Farahani, H., Goldansaz, S. H., and Sabahi, Q. (2012). A survey on the overwintering larval parasitoids of Ectomyelois ceratoniae in three regions in Iran. Crop Prot. 36, 52-57. doi: 10.1016/j.cropro.2012. 01.018

Li, Y., Hill, C. B., and Hartman, G. L. (2004). Effect of three resistant soybean genotypes on the fecundity, mortality, and maturation of soybean aphid (Homoptera: Aphididae). J. Econ. Entomol. 97, 1106-1111. doi: 10.1603/00220493(2004)097\%5B1106:eotrsg\%5D2.0.co;2

Mardani-Talaee, M., Nouri-Ganblani, G., Razmjou, J., Hassanpour, M., Naseri, B., and Asgharzadeh, A. (2016). Effects of chemical, organic and bio-fertilizers on some secondary metabolites in the leaves of bell pepper (Capsicum annuum) and their impact on life table parameters of Myzus persicae (Hemiptera: Aphididae). J. Econ. Entomol. 109, 1231-1240. doi: 10.1007/s13744-0170494-2

Mirsaeedghazi, H., Emam-Djomeh, Z., and Ahmadkhaniha, R. (2014). Effect of frozen storage on the anthocyanins and phenolic components of pomegranate juice. J. Food Sci. Technol. 51, 382-386. doi: 10.1007/s13197-0110504-Z

Mortazavi, S., Samih, M. A., Ghajarieh, H., and Jafari, A. (2015). Effect of some diets on demographic parameters of Ectomyelois ceratoniae (Zeller) (Lepidoptera: Pyralidae) in vitro. J. Plant Protec. Res. 55, 212-219. doi: 10.1515/jppr-20150028

Mortazavi, S., Samih, M. A., Ghajarieh, H., and Jafari, A. (2016). Effect of some diets on biological parameters of Apomyelois ceratoniae in laboratory and efficiency of natural pheromone traps in pomegranate orchards. J. Crop Protec. 5, 115-124. doi: 10.18869/modares.jcp.5.1.115

Nathan, S. S., Chung, P. G., and Murugan, K. (2005). Effect of biopesticides applied separately or together on nutritional indices of the rice leaffolder Cnaphalocrocis medinalis. Phytoparasitica 33, 187-195. doi: 10.1007/BF0302 9978

Navarro, S., Donahaye, E., and Calderon, M. (1986). Development of the carob moth, Spectrobates ceratoniae, on stored almonds. Phytoparasitica 14, 177-186. doi: 10.1007/BF02980485

Nawrot, J., Gawlak, M., Szafranek, J., Szafranek, B., Synak, E., Warchalewski, J. R., et al. (2010). The effect of wheat grain composition, cuticular lipids and kernel surface microstructure on feeding, egg-laying, and the development of the granary weevil, Sitophilus granarius (L.). J. Stored Prod. Res. 46, 133-141. doi: $10.1016 /$ j.jspr.2010.02.001

Nikooei, M., Fathipour, Y., Jalali Javaran, M., and Soufbaf, M. (2015). How different genetically manipulated Brassica genotypes affect life table parameters of Plutella xylostella (Lepidoptera: Plutellidae). J. Econ. Entomol. 108, 515-524. doi: $10.1093 /$ jee/tov018
Norouzi, A., Talebi, A., and Fathipour, A. Y. (2008). Development and demographic parameters of the Carob moth Apomyelois ceratoniae on four diet regimes. B. Insectol. 61, 291-297.

Nouri-Ganbalani, G., Borzoui, E., Shahnavazi, M., and Nouri, A. (2018). Induction of resistance against Plutella xylostella (L.) (Lep.: Plutellidae) by jasmonic acid and mealy cabbage aphid feeding in Brassica napus L. Front. Physiol. 9:859. doi: $10.3389 /$ fphys.2018.00859

Ode, P. J. (2006). Plant chemistry and natural enemy fitness: effects on herbivore and natural enemy interactions. Annu. Rev. Entomol. 51, 163-185. doi: 10.1146/ annurev.ento.51.110104.151110

Ramzi, S., Sahragard, A., and Zibaee, A. (2014). Effects of Citrullus colocynthis agglutinin on intermediary metabolism of Ectomyelois ceratoniae Zeller (Lepidoptera: Pyralidae). J. Asia Pac. Entomol. 17, 273-279. doi: 10.1016/j. aspen.2014.01.005

Ranjbar, M., Sendi, J. J., and Zibaee, A. (2011). Proteolytic activity in the midgut of Ectomyelois ceratoniae Zeller (Lepidoptera: Pyralidae), pomegranate carob moth. ISJ Invert. Surviv. J. 8, 132-142. doi: 10.2478/v10045-012-0061-0

Sarkhosh, A., Zamani, Z., Fatahi, R., and Ranjbar, H. (2009). Evaluation of genetic diversity among Iranian soft-seed pomegranate accessions by fruit characteristics and RAPD markers. Sci. Hortic. 121, 313-319. doi: 10.1016/j. scienta.2009.02.024

SAS Institute (2002). The SAS system for Windows. Cary, NC: SAS Institute.

Shakeri, M. (ed.) (2004). "A review on investigations on pomegranate neck worm in Iran," in A Proceeding on Evaluation of Finding and Current Problems Associated With Spectrobates Ceratoniae Management in Pomegranate, (Tehran: Ministry of Jihad-e- Agriculture).

Sobhani, M., Goldansaz, S. H., Hatami, B., and Hosseini, S. A. (2015). A field screening of pomegranate cultivars for resistance to the carob moth, Ectomyelois ceratoniae, and compatibility with its larval parasitoids. Int. J. Pest Manage. 61, 346-352. doi: 10.1080/09670874.2015.1069418

Soufbaf, M., Fathipour, Y., Karimzadeh, J., and Zalucki, M. P. (2010). Bottom-up effect of different host plants on Plutella xylostella (Lepidoptera: Plutellidae): a life-table study on canola. J. Econ. Entomol. 103, 2019-2027. doi: 10.1603/ EC10010

Soufbaf, M., Fathipour, Y., Zalucki, M. P., and Hui, C. (2012). Importance of primary metabolites in canola in mediating interactions between a specialist leaf-feeding insect and its specialist solitary endoparasitoid. Arthropod Plant Int. 6, 241-250. doi: 10.1007/s11829-012-9182-7

Soufbaf, M., Salehi, B., Kalantarian, N., Zanganeh, A. H., Fathollahi, H., Babaei, M., et al. (2017). Is sterile insect technique's efficiency affected by pomegranate variety in mixed cultivars? New insights from a case study on the carob moth, Apomyelois ceratoniae Zeller (Lepidoptera: Pyralidae) in Iran. Orient. Insects. 52, 1-11. doi: 10.1080/00305316.2017.1397064

SPSS Inc (2007). SPSS Base 16.0 User's Guide. Chicago, IL: SPSS Incorporation.

Tanner, H., and Brunner, H. R. (1979). Getraenke Analytik. Verlag Heller Chemie-Und Verwaltungsgeselschaft $\mathrm{mbH}$. D-7170. Germany: schwaebisch Hall.

Tezcan, F., Gültekin-Özgüven, M., Diken, T., Özçelik, B., and Erim, F. B. (2009). Antioxidant activity and total phenolic, organic acid and sugar content in commercial pomegranate juices. Food Chem. 115, 873-877. doi: 10.1016/j. foodchem.2008.12.103

Tsai, J. H., and Wang, J. J. (2001). Effects of host plant on biology and life table parameters of Aphis spiraecola (Hom: Aphididae). Environ Entomol. 30, 44-50. doi: 10.1603/0046-225X-30.1.44

Turfan, O., Turkyılmaz, M., Yemis, O., and Ozkan, M. (2011). Anthocyanin and colour changes during processing of pomegranate (Punica granatum L., cv. Hicaznar) juice from sacs and whole fruit. Food Chem. 129, 1644-1651. doi: 10.1016/j.foodchem.2011.06.024

Van Handel, E. (1985). Rapid determination of total lipids in mosquitoes. J. Am. Mosquito Contr. 1, 302-304.

Waldbauer, G. P. (1968). The consumption and utilization of food by insects. Adv. Insect Physiol. 5, 229-288. doi: 10.1016/S0065-2806(08)60230-1

War, A. R., Paulraj, M. G., Ahmad, T., Buhroo, A. A., Hussain, B., Ignacimuthu, S., et al. (2012). Mechanisms of plant defense against insect herbivores. Plant Signal. Behav. 7, 1306-1320. doi: 10.4161/psb.21663

War, A. R., Paulraj, M. G., War, M. Y., and Ignacimuthu, S. (2011). Differential defensive response of groundnut to Helicoverpa armigera (Hubner) 
(Lepidoptera: Noctuidae). J. Plant Interact. 6, 1-11. doi: 10.1080/17429145. 2011.587898

Warner, R. L., Barnes, M. M., Laird, E. F., and Lanham, M. D. (1990). Chemical control of carob moth, Ectomyelois ceratoniae (Lepidoptera.: Pyralidae), and various nitidulid beetles (Coleoptera) on 'Deglet Noor' dates in California. J. Econ. Entomol. 83, 2357-2361. doi: 10.1093/jee/83.6. 2357

Wrolstad, R. E., Durst, R. W., and Lee, J. (2005). Tracking color and pigment changes in anthocyanin products. Trends Food Sci. Tech. 16, 423-428. doi: 10.1016/j.tifs.2005.03.019

Yuval, B., Kaspi, R., Shloush, S., and Warburg, M. S. (1998). Nutritional reserves regulate male participation in mediterranean fruit fly leks. Ecol. Entomol. 23, 211-215. doi: 10.1046/j.1365-2311.1998.00118.x

Zare, D., Sendi, J. J., Jafary Nodoushan, A., and Khosravi, A. (2013). Life table parameters and biological characteristics of Apomyelois ceratoniae
Zeller (Lepidoptera: Pyralidae) on three cultivars of pomegranate. Arch. Phytopathol. Plant Protect. 46, 766-773. doi: 10.1080/03235408.2012.75 2141

Conflict of Interest: The authors declare that the research was conducted in the absence of any commercial or financial relationships that could be construed as a potential conflict of interest.

Copyright (c) 2019 Abedi, Golizadeh, Soufbaf, Hassanpour, Jafari-Nodoushan and Akhavan. This is an open-access article distributed under the terms of the Creative Commons Attribution License (CC BY). The use, distribution or reproduction in other forums is permitted, provided the original author(s) and the copyright owner(s) are credited and that the original publication in this journal is cited, in accordance with accepted academic practice. No use, distribution or reproduction is permitted which does not comply with these terms. 